\title{
Upregulation of estrogen receptor beta protein but not mRNA predicts poor prognosis and may be associated with enhanced translation in non-small cell lung cancer: a systematic review and meta-analysis
}

\author{
Wangyang Meng^, Yongde Liao^, Jiaping Chen, Yangwei Wang, Yunchong Meng, Kuo Li, Han Xiao^ \\ Department of Thoracic Surgery, Union Hospital, Tongji Medical College, Huazhong University of Science and Technology, Wuhan, China \\ Contributions: (I) Conception and design: W Meng, H Xiao; (II) Administrative support: Y Liao; (III) Provision of study materials or patients: Y Liao; \\ (IV) Collection and assembly of data: W Meng, H Xiao; (V) Data analysis and interpretation: W Meng, H Xiao, J Chen, Y Wang; (VI) Manuscript \\ writing: All authors; (VII) Final approval of manuscript: All authors. \\ Correspondence to: Han Xiao. Department of Thoracic Surgery, Union Hospital, Tongji Medical College, Huazhong University of Science and \\ Technology, Wuhan 430022, China. Email: 13260536972@163.com.
}

\begin{abstract}
Background: An increasing number of original studies suggest that estrogen receptor beta (ER $\beta)$ expression may be related to non-small cell lung cancer (NSCLC) prognosis; however, the evidence remains inconclusive and conflicting. We aimed to systematically evaluate the expression and prognostic value of ER $\beta$ in NSCLC, and to explain the inconsistency between ER $\beta$ protein and mRNA level.

Methods: PubMed, Embase, and Web of Science databases were searched for studies (published before October 6, 2020) reporting the prognostic value of ER $\beta$ protein expression in NSCLC. The pooled hazard ratios (HRs) with 95\% confidence intervals (CIs) for overall survival (OS) were calculated. Transcriptome and survival data of lung adenocarcinoma patients were obtained from public databases for differential expression and survival analyses. Immunohistochemistry (IHC) was performed to examine the ER $\beta$ protein expression in 39 NSCLC patients. Western blotting and RT-qPCR were performed to analyze ER $\beta$ expression in two paired NSCLC and normal adjacent tissue samples. The effect of methyltransferase-like 13 (METTL3) on ER $\beta$ expression was investigated in a lung cancer cell line.
\end{abstract}

Results: Meta-analysis of 23 studies with a total of 3744 patients demonstrated that high protein expression of overall ER $\beta$ and cytoplasmic ER $\beta$ indicated poor OS (HR: 1.05, 95\% CI: 1.00 to 1.10; HR: 1.48, 95\% CI: 1.13 to 1.95$)$ in NSCLC. For lung adenocarcinoma especially, high protein expression of both overall/ cytoplasmic ER $\beta$ and nuclear ER $\beta$ suggested poor OS (HR: 1.54, 95\% CI: 1.05 to 2.25; HR: 1.36, 95\% CI: 1.03 to 1.80). Bioinformatics analysis indicated the expression of ER $\beta$ mRNA was not associated with the prognosis of lung adenocarcinoma. Analysis of public databases showed that ER $\beta$ mRNA is not highly expressed in tumor tissues, however, IHC results revealed that ER $\beta$ protein is highly expressed in NSCLC tissues. We validated this inconsistency in ER $\beta$ expression in paired tumors and normal adjacent tissues from patients. Moreover, METTL3 knockdown in the A549 cell line downregulated ER $\beta$ protein expression but not ER $\beta$ mRNA expression.

Conclusions: Our study elucidated the inconsistency between ER $\beta$ protein and mRNA expression levels and their prognostic values. The results indicated that METTL3-driven enhanced translation in NSCLC may cause this inconsistency.

^ ORCID: Wangyang Meng, 0000-0001-8725-3294, Yongde Liao: 0000-0001-7989-2969; Han Xiao, 0000-0003-3787-3529. 


\begin{abstract}
Keywords: Estrogen receptor beta (ERß); non-small cell lung cancer (NSCLC); prognosis; methyltransferase-like 13 (METTL3); translation
\end{abstract}

Submitted Apr 14, 2021. Accepted for publication Jun 19, 2021.

doi: $10.21037 /$ jtd-21-658

View this article at: https://dx.doi.org/10.21037/jtd-21-658

\section{Introduction}

Estrogen receptor beta (ER $\beta$, also known as ESR2) is one of the two classical subtypes of the estrogen receptor (1) and is widely expressed in the lung. Lung cancer cells exhibit a stronger ER $\beta$ protein expression than normal lung cells (2-4). Previous studies, including ours, have reported that ER $\beta$ in the nucleus acts as a transcription factor that exerts effects on lung carcinogenesis $(5,6)$; and ER $\beta$ in the cytosol participates in the signaling pathways that promote nonsmall cell lung cancer (NSCLC) progression and metastasis $(7,8)$, leading to a poor prognosis in NSCLC patients.

Despite unraveling the putative role of ER $\beta$ in lung cancer, the prognostic value of ER $\beta$ protein expression reported in different studies is not consistent $(9,10)$. A meta-analysis in 2015 reported a favorable effect of ER $\beta$ on NSCLC survival (11). Another meta-analysis of 11 studies reported that ER $\beta$ is not an independent predictor of NSCLC survival (12). These two meta-analyses lacked evaluation by different subcellular localizations of ER $\beta$, and neither of these studies considered the effect of ER $\beta$ in lung adenocarcinoma. Several additional original studies were published subsequently.

Studies focusing on the expression and prognostic value of ER $\beta$ mRNA have shown negative results. ER $\beta$ mRNA expression is not upregulated in lung cancer tissues (13). In 2015, a meta-analysis showed that ER $\beta$ mRNA is not a prognostic factor for NSCLC (14). Therefore, we suppose that the expression of ER $\beta$ protein and mRNA is not consistent in NSCLC, and that this inconsistency is reflected in their prognostic values. There might be an abnormal translation control that can upregulate the protein expression of ER $\beta$ in the presence of low mRNA expression level, which further affects the prognosis. As the most abundant base modification of RNA, N6-methyladinosine $\left(\mathrm{m}^{6} \mathrm{~A}\right)$ drives translation initiation in human cells (15). METTL3 acts as a key enzyme in RNA $\mathrm{m}^{6} \mathrm{~A}$ modification. In 2016, Lin et al. (16) reported that METTL3 promotes the translation of abundant mRNAs in human cancer cells, revealing the important role of translation control in cancer cells.

The expression of ER $\beta$ and its relationship with lung cancer survival have not been systematically evaluated to date. Therefore, in this study, we conducted a metaanalysis with specific subgroups and a large sample size. By combining abundant transcriptome data, we illustrated the prognostic value of ER $\beta$ protein and mRNA. Expression data from clinical samples and public databases were included to explore the difference between ER $\beta$ protein and mRNA expression. Furthermore, we verified this difference in paired tissue samples from NSCLC patients. Finally, we explored the possible mechanism of METTL3-driven translation regulation in cell lines. In summary, based on our studies of estrogen-mediated NSCLC progression (7,8,17-19), we provide insights into ER $\beta$ expression profiles, and the possibility of anti-estrogen therapy in NSCLC.

We present the following article in accordance with the PRISMA reporting checklist (available at https://dx.doi. org/10.21037/jtd-21-658) (20).

\section{Methods}

\section{Literature search}

We comprehensively searched the PubMed, Web of Science, and Embase databases for articles published before October 6, 2020 (the search strategy is detailed in Table S1) that analyzed the prognostic value of ER $\beta$ protein expression in NSCLC patients. We identified studies using medical subject headings (MeSH) from PubMed to develop a controlled vocabulary where applicable. In addition to $\mathrm{MeSH}$, we included relevant free-text entry terms.

\section{Selection criteria and study selection}

Original articles that achieved all the following criteria were included: (I) presented data, including different 
histological types, from primary NSCLC patients; (II) detected ER $\beta$ protein expression in primary tumor tissues using immunohistochemistry (IHC); (III) provided detailed clinical and pathological features of the study population; (IV) addressed the prognostic value of tumor ER $\beta$ expression using survival analysis.

Articles that achieved any of the following criteria were excluded: (I) estimated the prognostic value for subtypes of ER $\beta$ only; (II) considered disease-free survival, recurrencefree survival, or progression-free survival as an endpoint but not overall survival (OS).

After removing duplicate studies, two investigators (W Meng and $\mathrm{H}$ Xiao) initially screened the titles and abstracts of the identified records for full-text review. Disagreements were resolved by consensus.

\section{Data extraction}

Using a pre-specified data collection sheet, two investigators (W Meng and $\mathrm{H}$ Xiao) independently extracted data from the retrieved articles, and agreement was achieved in group discussions. The extracted data included the authors, year of publication, country or region, sample size, tumor stage, composition of different histology types, median/mean and range of age, follow-up duration, epidermal growth factor receptor (EGFR) mutation status, aromatase expression status, sample type, detection method of ER $\beta$ expression, ER $\beta$ subcellular localization, positive cut-off definition, number of positive cases, antibody type, and covariates adjustment. We selected OS as the endpoint for our metaanalysis because OS is widely used as a significant prognostic indicator. Hazard ratios (HRs) for the association between three subcellular localizations of ER $\beta$ [cytoplasmic ER $\beta$, nuclear ER $\beta$, and overall ER $\beta$ (cytoplasmic and nuclear ER $\beta)]$ and OS were extracted.

\section{Quality assessment}

We used the Newcastle-Ottawa Scale (NOS) (21) for cohort studies to assess the methodological quality of the included studies. It is a nine-point scoring system that considers participant selection, exposure measurement, ascertainment of outcomes, covariate adjustment, and adequacy of followup. A high-quality study was defined as a study with at least seven points. Two reviewers (W Meng and H Xiao) independently assessed the quality of the included articles, and disagreements were resolved through group discussions.

\section{Statistical analysis of meta-analysis}

HRs and the corresponding 95\% confidence intervals (CIs) were considered the effect sizes in this study. For studies in which HRs and 95\% CIs were not available, we used the method described by Parmar et al. (22) to derive estimates from the published Kaplan-Meier survival curves. The most adjusted study-specific HRs and 95\% CIs were primarily pooled using a random-effects model and the inverse variance method. Heterogeneity between studies was assessed using the $\mathrm{I}^{2}$ index, and we considered $\mathrm{I}^{2}<50 \%$ as low heterogeneity, $\mathrm{I}^{2}$ between $50 \%$ and $75 \%$ as medium heterogeneity, and $\mathrm{I}^{2}>75 \%$ as high heterogeneity. If the heterogeneity was low $\left(\mathrm{I}^{2}<50 \%\right)$, a fixed-effects model was used. Subgroup analyses were performed based on several variables, including histology type, geographical location and whether a multivariate or univariate analysis was performed. Sex-specific HRs were also pooled using data from the studies. For study groups with relatively high heterogeneity $\left(\mathrm{I}^{2}>50 \%\right)$, we performed sensitivity analysis (in the random-effects model) using a leave-one-out strategy to investigate the sources of heterogeneity.

Publication bias was assessed using funnel plots and the Egger's test. All statistical analyses for the meta-analysis were performed using STATA version 16.0 (Stata Corp, College Station, TX, USA); a 2-sided P value of $<0.05$ was considered statistically significant.

\section{Survival analysis of gene expression in lung adenocarcinoma}

After the removal of 59 normal tissues, we analyzed the prognostic value of four genes [ESR2, ESR1 (estrogen receptor alpha; ER $\alpha$ ), G-protein coupled estrogen receptor 1 (GPER1) and CYP19A1 (also known as aromatase, which is a key enzyme for estrogen synthesis)] in 526 lung adenocarcinoma tissues from The Cancer Genome Atlas (TCGA)-lung adenocarcinoma (LUAD). The "survminer" and "survival" packages were used to draw Kaplan-Meier curves. The Kaplan-Meier Plotter (http://kmplot.com/) is an online database used to assess the association of genes with survival in four types of cancer (lung, breast, gastric, and ovarian cancer). It was used to verify the prognostic value of the four target genes in lung adenocarcinoma 
patients $(\mathrm{n}=719)$.

\section{Differential expression analysis of the transcriptome in lung adenocarcinoma}

Based on the findings of the relationship between ER $\beta$ and lung cancer at the protein level using meta-analysis, we performed bioinformatics analysis to further explore the relationship between ER $\beta$ and lung cancer at the transcriptional level.

To quantify ER $\beta$ mRNA expression in lung adenocarcinoma, RNA-seq data of a lung adenocarcinoma cohort (tumor tissues $=526 v s$. normal tissues $=59$ ) from TCGA and those of normal lung tissues $(n=288)$ from the Genotype-Tissue Expression (GTEx) were obtained from the University of California Santa Cruz Xena platform (https://xenabrowser.net/datapages/). RNA-seq data from the GTEx (https://commonfund.nih.gov/GTEx/) project were used to reduce the bias in the data from TCGALUAD. ESR2, ESR1, GPER1 and CYP19A1 were selected as the target genes for differential expression analyses. The $\mathrm{R}$ package "limma" was used to screen the differentially expressed genes (DEGs) among the four target genes. Genes with an absolute value of $\log \mathrm{FC}$ (the logarithm of fold change) $>1$ and $\mathrm{P}<0.05$ were defined as the DEGs. The results of "limma" analysis are presented in the form of a heatmap. Four gene expression profile datasets (GSE10072, GSE40791, GSE32863, and GSE43458) of lung adenocarcinoma were obtained from the Gene Expression Omnibus (GEO) for further validation of the above DEG analysis results.

\section{Patients and tissue specimens}

Paired samples of primary NSCLC tumors and corresponding normal adjacent tissues from 39 Chinese patients for IHC were obtained at the time of surgical resection at the Department of Thoracic Surgery, Tongji Hospital of Huazhong University of Science and Technology Tongji Medical College (Wuhan, China).

Paired samples of primary tumors and normal adjacent tissues from two patients for western blotting and RTqPCR were obtained at the time of surgical resection at the Department of Thoracic Surgery, Union Hospital of Huazhong University of Science and Technology Tongji Medical College (Wuhan, China). The exterior of the NSCLC tissue which is a hard white part, was selected. The study was approved by the Ethics or Institutional
Review Board of Union Hospital, Tongji Medical College, Huazhong University of Science and Technology, and written informed consent was obtained from all subjects in accordance with the Declaration of Helsinki (as revised in 2013). All of the patients had sufficient tissue blocks available for the analysis of ER $\beta$ expression.

\section{Immunobistochemical analyses}

Sample processing and IHC were performed as previously described (17). Rabbit anti-human ER $\beta$ polyclonal antibody (dilution 1:50, Proteintech 14007-1-AP) was purchased from Proteintech (Wuhan, China). Protein expression levels were independently scored by two pathologists. Immunoreactivity scores of cancer tissue samples were determined based on staining intensity and positive staining area according to the method described by Tang et al. (17). Proportion of the positive cells was scored as follows: 1 , $\leq 25 \%$ positive cells; $2,25-50 \%$ positive cells; $3,50-75 \%$ positive cells; and $4,>75 \%$ positive cells. Staining intensity was evaluated as follows: 1 , negative; 2 , weakly positive; 3 , moderately positive; and 4 , strongly positive. A score of 1-8 was obtained by adding the staining intensity score and the proportion score. A total score $\geq 5$ was defined as high expression, and a score $\leq 4$ was defined as low expression. These criteria were based on the evaluations reported by Nose et al. and Kawai et al. $(23,24)$.

\section{Cell lines and culture conditions}

The human NSCLC cell line A549 was purchased from the American Type Culture Collection (ATCC, Manassas, VA, USA), grown for 2 weeks, and passaged four times before freezing aliquots for subsequent analyses. The cell lines were tested and authenticated by ATCC. The cells were cultured in RPMI 1640 medium supplemented with $10 \%$ fetal bovine serum (FBS) and $1 \%$ penicillin/streptomycin and then incubated in a humidified atmosphere with $5 \%$ $\mathrm{CO}_{2}$ at $37^{\circ} \mathrm{C}$.

\section{Cell transfection}

Transfection of small interfering RNA (siRNA) was performed using Lipofectamine 3000 (Invitrogen; Shanghai, China) according to the manufacturer's instructions. siRNAs targeting METTL3 (siRNA_METTL3: CTGCAAGTATGTTCACTATGA) and control siRNAs (siRNA_NC) were obtained from Ribobio Co., Ltd, 
Guangzhou China.

\section{Western blotting of cultured cells and NSCLC samples}

Lung cancer tissues or cell lines were lysed in RIPA buffer, followed by homogenization and determination of protein concentration. Thereafter, $20 \mu \mathrm{g}$ of protein was loaded for SDS-PAGE and transferred onto PVDF membranes. Immunoblotting was performed to detect protein expression. The corresponding antibodies included METTL3 (Abcam 195352), ER $\beta$ (Proteintech 14007-1$\mathrm{AP}$ ), and GAPDH (Proteintech 60004-1-Ig). Specifically bound HRP-conjugated secondary antibodies were detected using an ECL detection system (ChemiDocTM XRS+ machine, Bio-Rad Laboratories). Densitometric analyses were performed using ImageJ software. Relative quantification was performed after normalization to GAPDH band intensities. A Mann-Whitney test was performed to assess the difference in protein expression between the groups. Each experiment was performed in triplicates and repeated at least three times.

\section{$R N A$ isolation and $R T-q P C R$}

Total RNA was extracted from NSCLC tissues (preserved in RNA Keeper Tissue Stabilizer, Vazyme Biotech Co. LTD, Nanjing, China) and cells using TRIzol (Invitrogen), following the manufacturer's instructions. $1 \mu \mathrm{g}$ total RNA was reverse transcribed using SuperScript ${ }^{\circledR}$ III Reverse Transcriptase (Invitrogen). Quantitative RTPCR was performed using SYBR ${ }^{\circledR}$ Green PCR Master Mix with the StepOne Real-Time PCR System (Applied Biosystems). GAPDH was used as the internal control for the normalization. The primers were purchased from Tsingke Co. LTD, Beijing, China. Primer information from PrimerBank is shown in Table S2.

\section{Results}

\section{Literature search}

Electronic searches identified 2,845 citations from PubMed, Web of Science and Embase, of which 1,764 titles and abstracts were reviewed. After the excluding 1,688 records, the full texts of 76 articles were further reviewed (Figure 1). A total of 23 unique studies in 22 articles met our selection criteria and were included in the meta-analysis.

\section{Characteristics and quality of the included studies}

The characteristics of the included studies are summarized in Table 1. The included studies reported data from a total of 3,744 patients. All studies were published between 2005 and 2020, including 22 retrospective cohort studies and one prospective cohort study. Fifteen studies from fourteen articles were on NSCLC, and eight studies were on lung adenocarcinoma (25-32).

All studies measured the protein expression of ER $\beta$ in tumor tissue using IHC. Six studies included cytoplasmic ER $\beta$ (2,10,25,33-35), 16 studies included nuclear ER $\beta$ $(9,10,23,26-29,31,32,36-40)$, and five studies included overall ER $\beta$, which considered cytoplasmic and nuclear ER $\beta$ expression $(2,30,32,34,41)$. Four studies reported two HRs for these different subcellular localizations of $\operatorname{ER} \beta(2,10,32,34)$. Navaratnam et al. included two distinct studies that reported two HRs for nuclear ER $\beta$ (38). Eight studies performed multivariate analyses of HRs to adjust for sex, age, stage at diagnosis, or smoking status $(2,9,10,28,34,39,42)$. Fourteen studies were performed in East Asia $(9,23,25-27,29-33,35,40,41)$, six in North America $(2,10,28,34,38,42)$, two in Western Europe $(37,39)$ and one in South America (36). The tumor stages of patients in most studies were stage I-IV or I-III. He (in 2015) et al. (33) and He (in 2019) et al. (32) studied stage IV lung cancer patients only. Monica et al. (37) studied stage III-IV patients, and Mauro et al. (36) used stage I patients.

The quality of the studies was carefully assessed using the NOS, with scores ranging from 7 to 9 (Table 2). Overall, three studies had a score of 9 , eight studies had a score of 8 , and the other twelve studies had a score of 7 , which led to an average score of 7.61. Detailed descriptions of these studies are summarized in Table S3.

\section{Prognostic value of ERß protein expression in different subcellular localizations}

Because four studies reported two HRs based on the different subcellular localizations of $\operatorname{ER} \beta(2,10,32,34)$, we performed a meta-analysis by different subcellular localizations of ER $\beta$ (overall ER $\beta$, cytoplasmic ER $\beta$, and nuclear ER $\beta$ ) separately to ensure that the HRs of different ER $\beta$ subcellular localizations in the same study population were not pooled together (Figure 2). High overall ER $\beta$ expression was associated with a poorer OS (HR: 1.05; 95\% CI: 1.00 to $1.10, \mathrm{P}=0.034)$ than low overall $\mathrm{ER} \beta$ expression, 


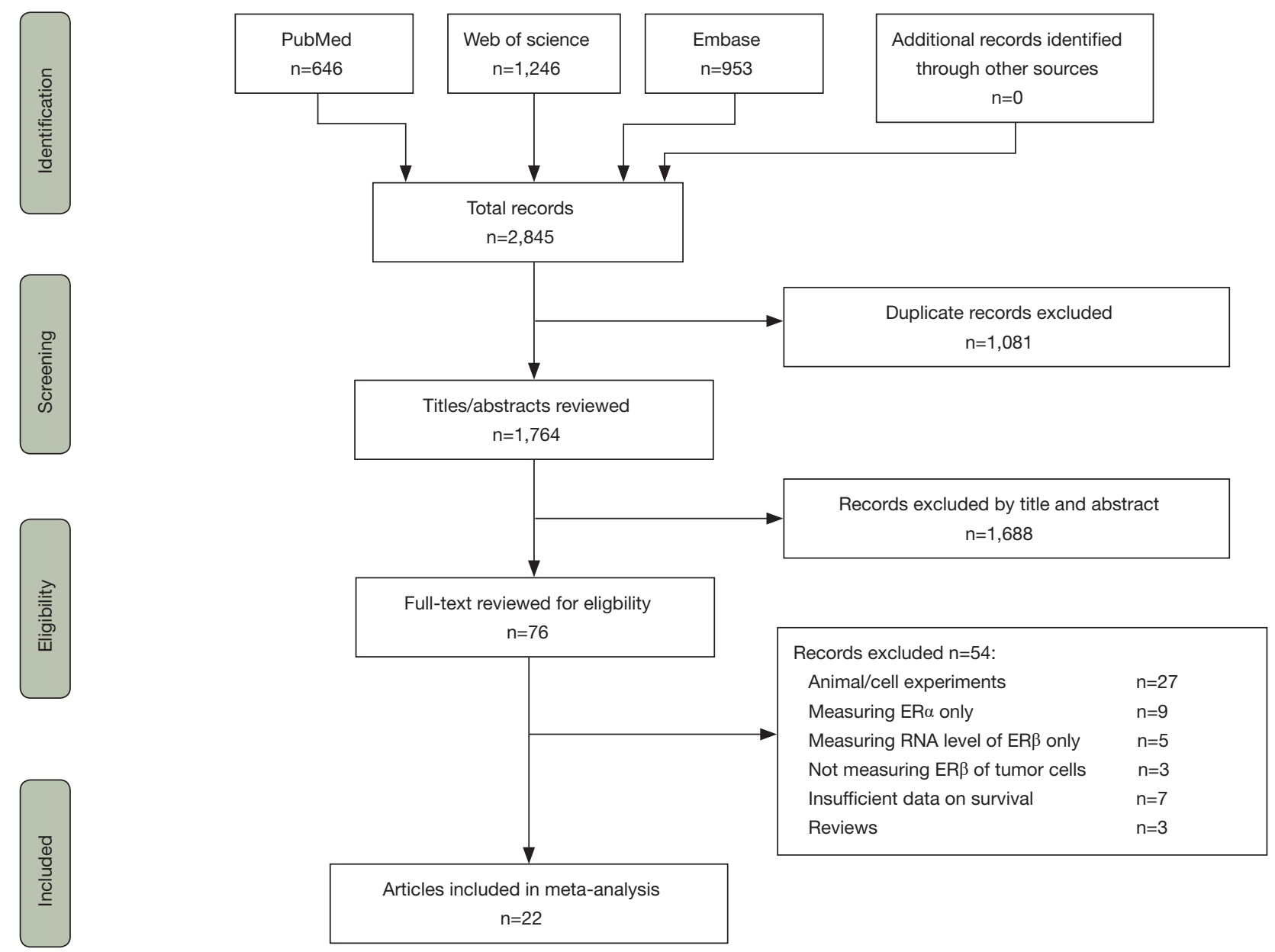

Figure 1 Search results and study selection process. ER $\beta$, estrogen receptor beta; ER $\alpha$, estrogen receptor alpha.

and there was no evidence of significant heterogeneity across the studies $\left(\mathrm{I}^{2}=0.0 \%, \mathrm{P}=0.730\right)$. High cytoplasmic ER $\beta$ expression was associated with an even poorer OS than those with low expression, with a pooled HR of 1.48 (95\% CI: 1.13 to $1.95, \mathrm{P}=0.005)$, and moderate heterogeneity was indicated using a random-effects model $\left(\mathrm{I}^{2}=53.4 \%\right.$, $\mathrm{P}=0.057)$. Nuclear ER $\beta$ expression was not a predictor of OS, achieving a pooled HR of 1.08 (95\% CI: 0.89 to 1.31 , $\mathrm{P}=0.501)$; moderate heterogeneity was indicated using a random effects model $\left(\mathrm{I}^{2}=47.5 \%, \mathrm{P}=0.018\right)$.

\section{Subgroup analyses and sources of heterogeneity}

\section{Subgroup analyses of different histological types}

ER $\beta$ is highly expressed in NSCLC and is closely related to the progression of lung adenocarcinoma; therefore, subgroup analysis was performed to investigate potential sources of heterogeneity between studies and assess the consistency of conclusions between lung adenocarcinoma patients and NSCLC patients. We divided all of the studies into two subgroups: studies specific to adenocarcinoma and studies that did not differentiate the histological types of NSCLC.

Among the eight adenocarcinoma studies, five studies included nuclear $\operatorname{ER} \beta$ (26-29,31,32), two studies included overall $\operatorname{ER} \beta(30,32)$, and only one study reported cytoplasmic ER $\beta$ (25). Therefore, we performed a combined analysis of the three overall ER $\beta$ and cytoplasmic ER $\beta$ studies $(25,30,32)$ (Figure $3 A$ ) and concluded that patients with high expression of overall/ cytoplasmic ER $\beta$ had statistically longer OS than those with low expression (HR: 1.54, 95\% CI: 1.05 to 2.25). Notably, high expression of nuclear ER $\beta$ was associated with poor OS in adenocarcinoma patients, with an HR of 


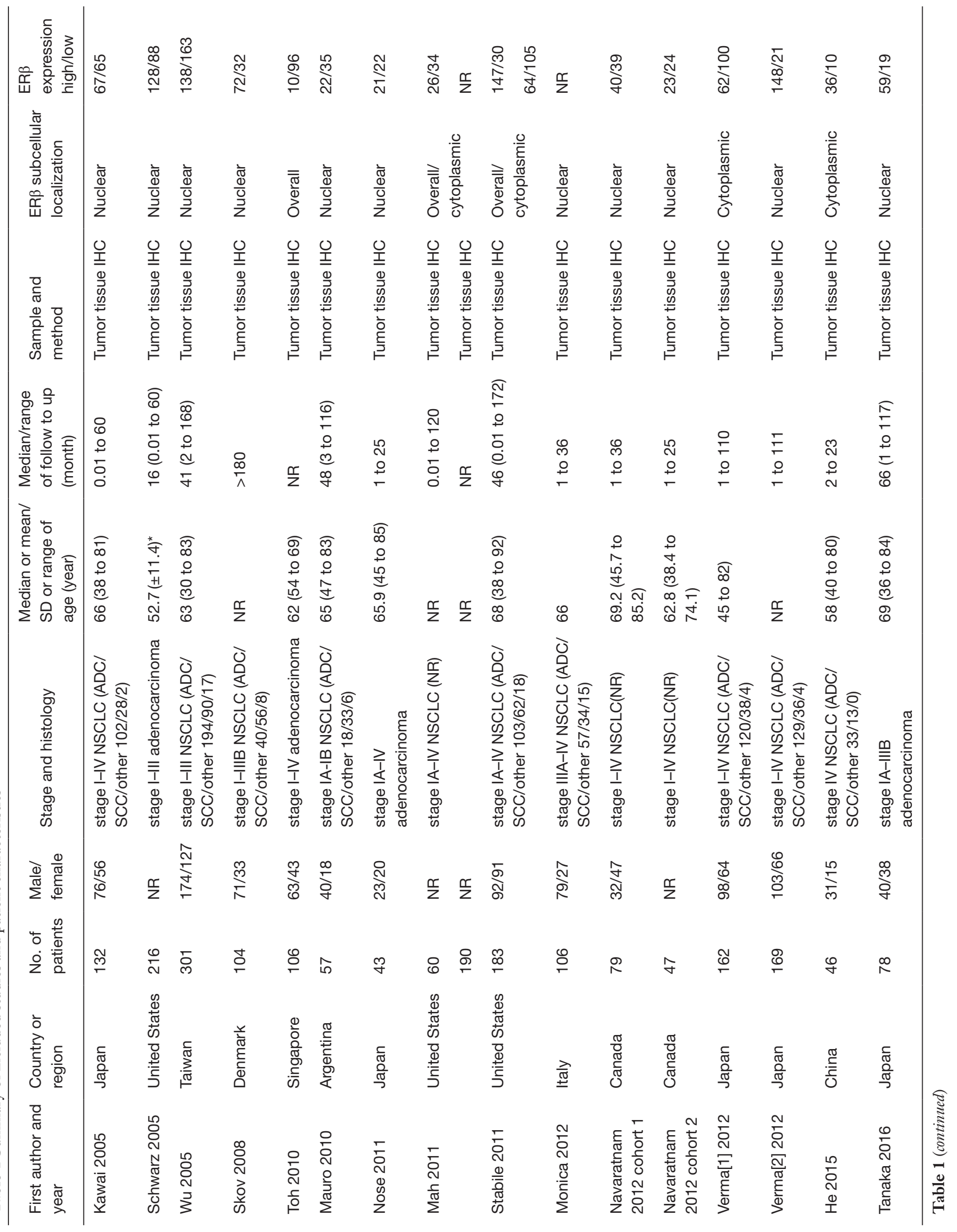




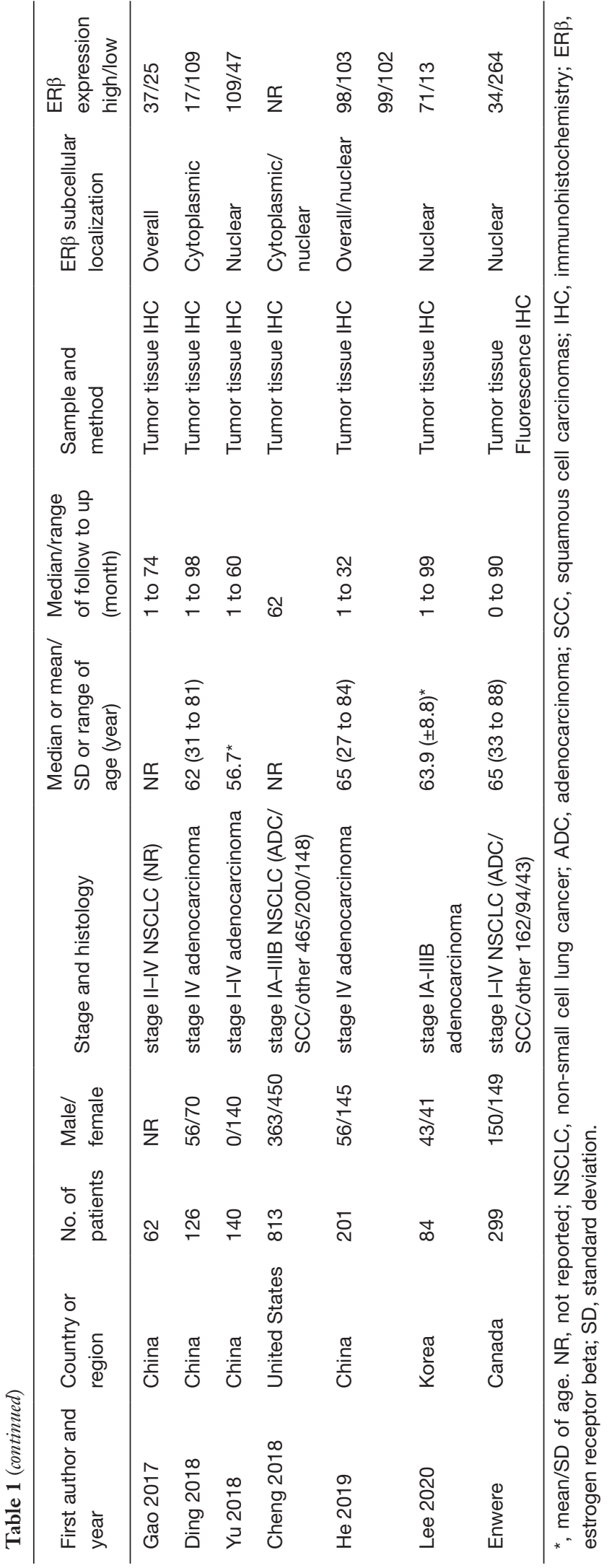

1.36 (95\% CI: 1.03 to 1.80$)$.

For the 15 studies that did not differentiate the histological types of NSCLC (Figure 3B), high overall ER $\beta$ expression and high cytoplasmic ER $\beta$ expression were associated with poor OS (HR: $1.05,95 \%$ CI: 1.00 to 1.10 and HR: $1.39,95 \%$ CI: 1.06 to 1.83$)$, and the result indicated no significant association between nuclear ER $\beta$ and OS (HR: 0.99, 95\% CI: 0.80 to 1.22 ).

\section{Subgroup analyses of other study characteristics}

Subgroup analyses were also performed for geographical location and based on whether a multivariate or univariate analysis was used (Table 3). The results indicated that high cytoplasmic ER $\beta$ expression was related with a poorer OS than low cytoplasmic ER $\beta$ expression in the multivariate analysis group (which was also the North America study group, HR: $1.56,95 \%$ CI: 1.28 to 1.89$)$. These two characteristics may have contributed to the heterogeneity in cytoplasmic ER $\beta$ and nuclear ER $\beta$ groups because substantial heterogeneity was observed in the univariate analysis and the Eastern Asia and Europe study groups.

We also pooled sex-specific HRs using data from studies that reported associations separately for men and women (Table 3; Figure S1). The results showed that high nuclear ER $\beta$ expression may be associated with a poor OS in women (HR: 1.62, 95\% CI: 1.13 to 2.32), and that nuclear ER $\beta$ expression had no prognostic value in men (HR: 0.66, 95\% CI: 0.32 to 1.36 ).

\section{Sensitivity analyses}

We performed sensitivity analyses using a leave-one-out strategy to evaluate the source of heterogeneity in the cytoplasmic ER $\beta$ group (Figure 2B). When we excluded, $\mathrm{He}$ (in 2015) et al. (33), the pooled HR was 1.61 (95\% CI: 1.35 to 1.92$)$ and the heterogeneity between studies was markedly reduced $\left(\mathrm{I}^{2}=0.0 \%, \mathrm{P}=0.692\right)$. When we excluded any other single study in turn, the pooled HR of the remaining studies was not substantially altered and ranged from 1.39 (95\% CI: 1.06 to 1.83 ) to 1.47 (95\% CI: 1.06 to 2.03) (Figure 2B), indicating that $\mathrm{He}$ (2015) et al. (33), which focused on stage IV lung adenocarcinoma only and had a relatively small sample size, may be the main source of heterogeneity in the cytoplasmic ER $\beta$ group.

\section{Publication bias of the included studies}

We performed publication bias analyses for the nuclear ER $\beta$ 


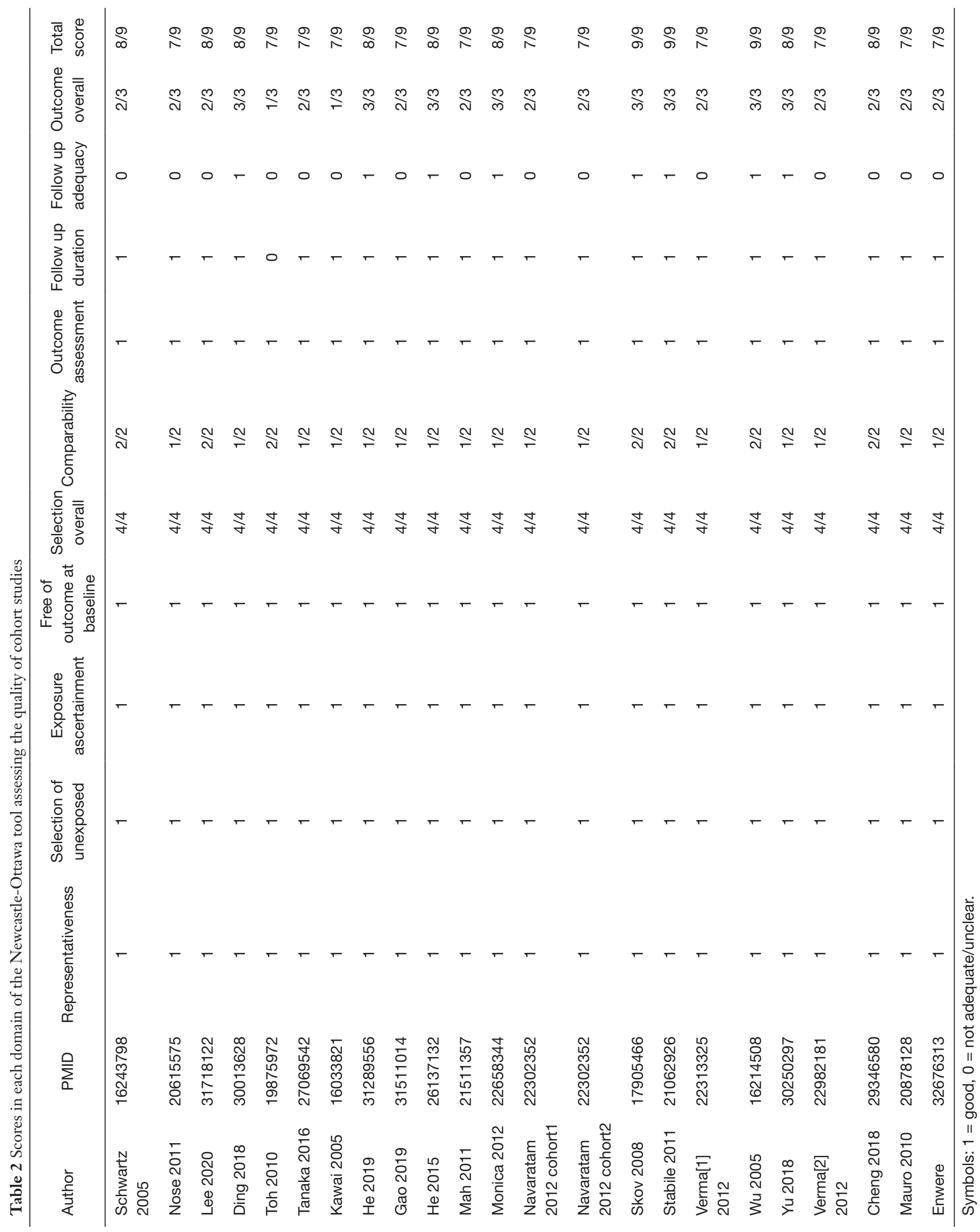


A
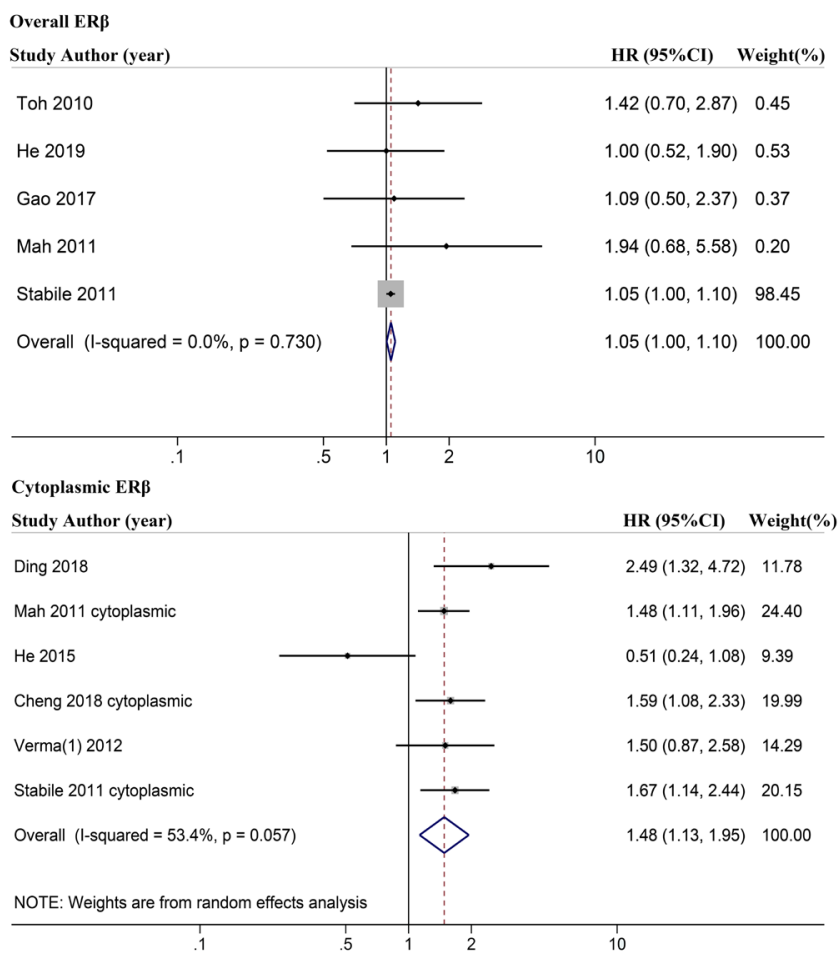

Nuclear ER $\beta$

Study Author (year)

He 2019 nuclear

Kawai 2005

Monica 2012

Navaratnam 2012 cohort 1

Navaratnam 2012 cohort2

Skov 2008

Verma(2) 2012

Wu 2005

Yu 2018

Mauro 2010

Cheng 2018 nuclear

Nose 2011

Schwartz 2005

Enwere 2020

Lee 2020

Tanaka 2016

Overall (l-squared $=47.5 \%, p=0.018$ )

NOTE: Weights are from random effects analysis

random effects analysis
HR (95\%CI) Weight(\%)

$1.05(0.53,2.05) \quad 5.24$

$0.77(0.35,1.74) \quad 4.14$

$1.75(1.00,3.03) \quad 6.67$

$1.42(0.74,2.72) \quad 5.50$

$0.87(0.46,1.66) \quad 5.60$

$0.97(0.76,1.26) \quad 11.96$

$0.72(0.30,0.98) \quad 6.18$

$0.72(0.50,1.03) \quad 9.83$

$2.18(1.28,3.71) \quad 6.98$

$0.37(0.14,0.99) \quad 3.06$

$1.30(0.91,1.85) \quad 9.95$

$0.74(0.19,2.96) \quad 1.72$

$0.93(0.57,1.52) \quad 7.59$

$1.16(0.77,1.76) \quad 8.87$

$1.34(0.40,4.50) \quad 2.15$

$1.08(0.89,1.31) \quad 100.00$
$2.18(1.03,4.62) \quad 4.55$
B

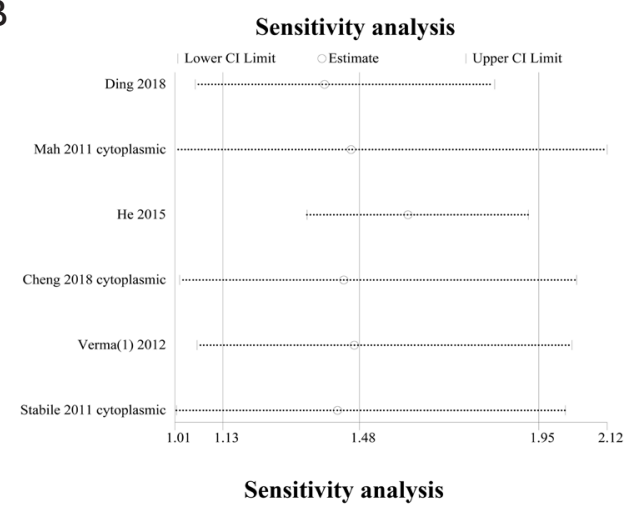

Cytoplasmic ER $\beta$

$\begin{array}{lll}\text { Study Author (year) } & \text { HR (95\%CI) Weight(\%) }\end{array}$

Ding 2018

Mah 2011 cytoplasmic

Cheng 2018 cytoplasmic

Verma(1) 2012

Stabile 2011 cytoplasmic

Overall (1-squared $=0.0 \%, p=0.692$ )

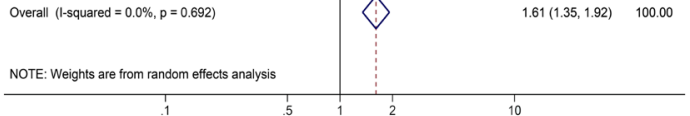

C

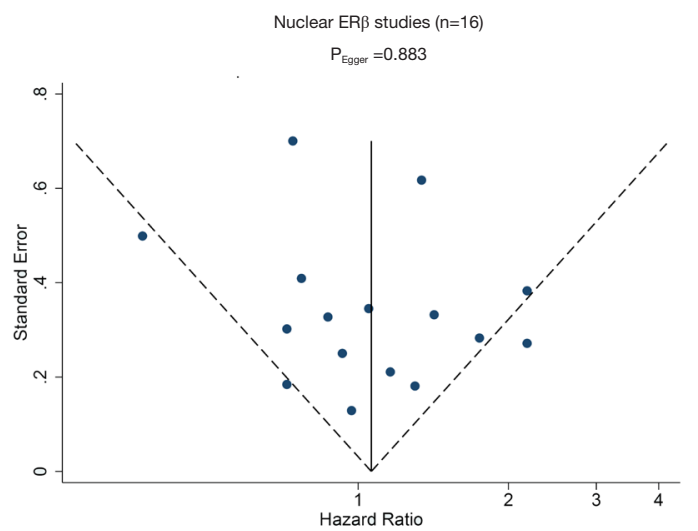

Figure 2 Forest plots of associations between ER $\beta$ protein expression and OS. (A) Effect of overall ER $\beta$, cytoplasmic ER $\beta$, and nuclear ER $\beta$ on OS of NSCLC (included lung adenocarcinoma-specific studies). (B) Sensitivity analyses for cytoplasmic ER $\beta$ using a leave-one-out strategy and forest plot for cytoplasmic ER $\beta$ after exclusion of He et al.'s (in 2015) study. (C) Funnel plot of Publication bias using Egger's test for nuclear ER $\beta$ group. HR, hazard ratio; CI, confidence interval; ER $\beta$, estrogen receptor beta. The size of the blocks or diamonds represents the weight, and the length of the straight line represents the width of $95 \%$ CI. Each dot represents a single study in the funnel plot. 
A
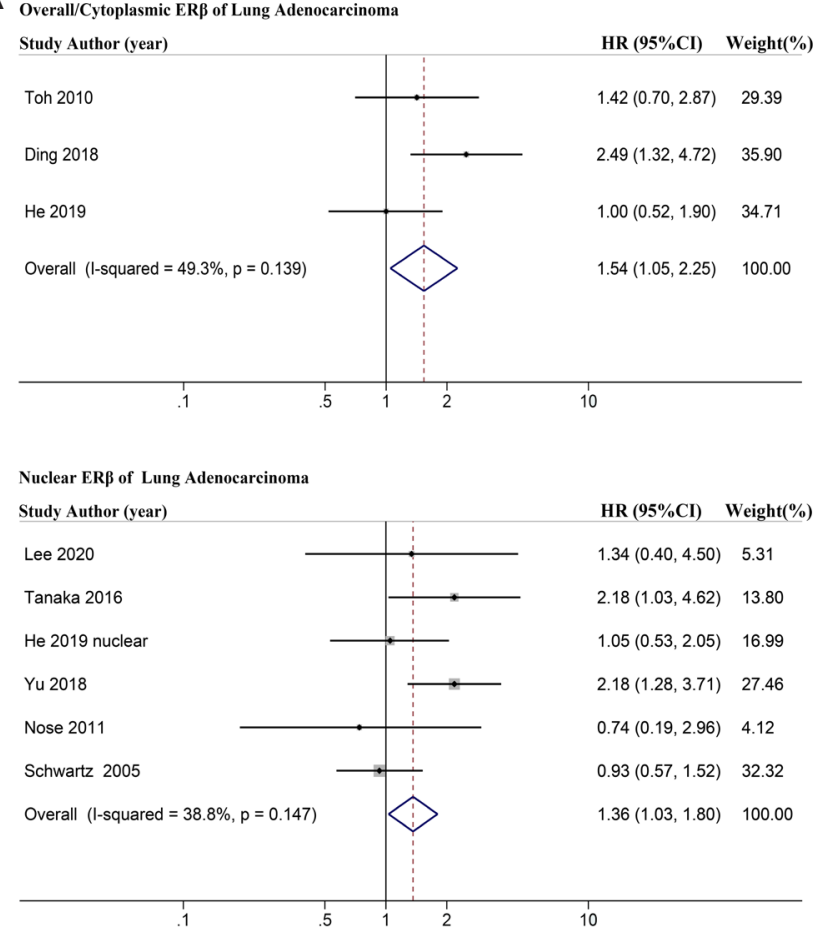

B

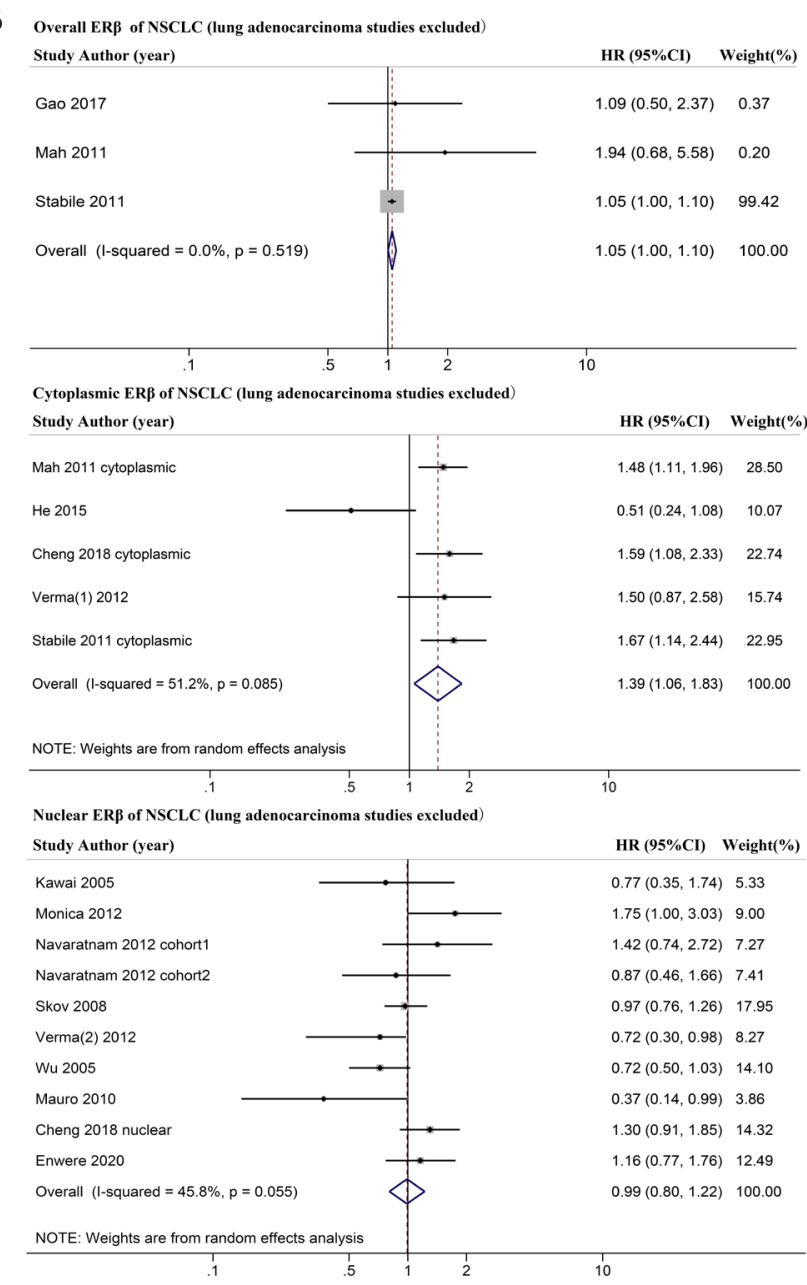

Figure 3 Subgroup analysis of associations between ER $\beta$ protein expression and OS. (A) Effect of overall/cytoplasmic ER $\beta$ and nuclear ER $\beta$ on OS of lung adenocarcinoma. (B) Effect of overall ER $\beta$, cytoplasmic ER $\beta$, and nuclear ER $\beta$ on OS of NSCLC (excluded lung adenocarcinoma-specific studies). The size of the blocks or diamonds represents the weight, and the length of the straight line represents the width of $95 \%$ CI. HR, hazard ratio; CI, confidence interval; ER $\beta$, estrogen receptor beta.

group (n=16, Figure 2C) and NSCLC nuclear ER $\beta$ group $(\mathrm{n}=10$, Figure S2). There was some evidence of publication bias in the inspection of the funnel plot, with two studies reporting standard errors (SEs) greater than those of other studies, however, the Egger's test was not significant ( $\mathrm{P}=0.883$ for nuclear ER $\beta$ group and $\mathrm{P}=0.616$ for NSCLC nuclear ER $\beta$ group).

\section{Survival analysis of the ERß mRNA expression in lung adenocarcinoma}

Survival analyses were performed with prognostic information from the tumor samples of TCGA-LUAD $(\mathrm{n}=526)$, and the mRNA expression of none of the four genes showed statistical prognostic value (Figure 4, Figure S3). The results from the Kaplan-Meier Plotter analysis of 719 patients with lung adenocarcinoma patients indicated a non-significant prognostic value of ER $\beta$ mRNA expression (HR: $1.23,95 \%$ CI: 0.98 to 1.55 ) (Figure 4B). These results indicate that the ER $\beta$ mRNA expression may not be a prognostic predictor of lung adenocarcinoma.

\section{Patient characteristics}

Among the 39 patients for IHC, 23 (59.0\%) were men and $16(41.0 \%)$ were women. The clinicopathological factors of 
Table 3 Analyses of hazard ratios of overall survival according to ER $\beta$ protein expression

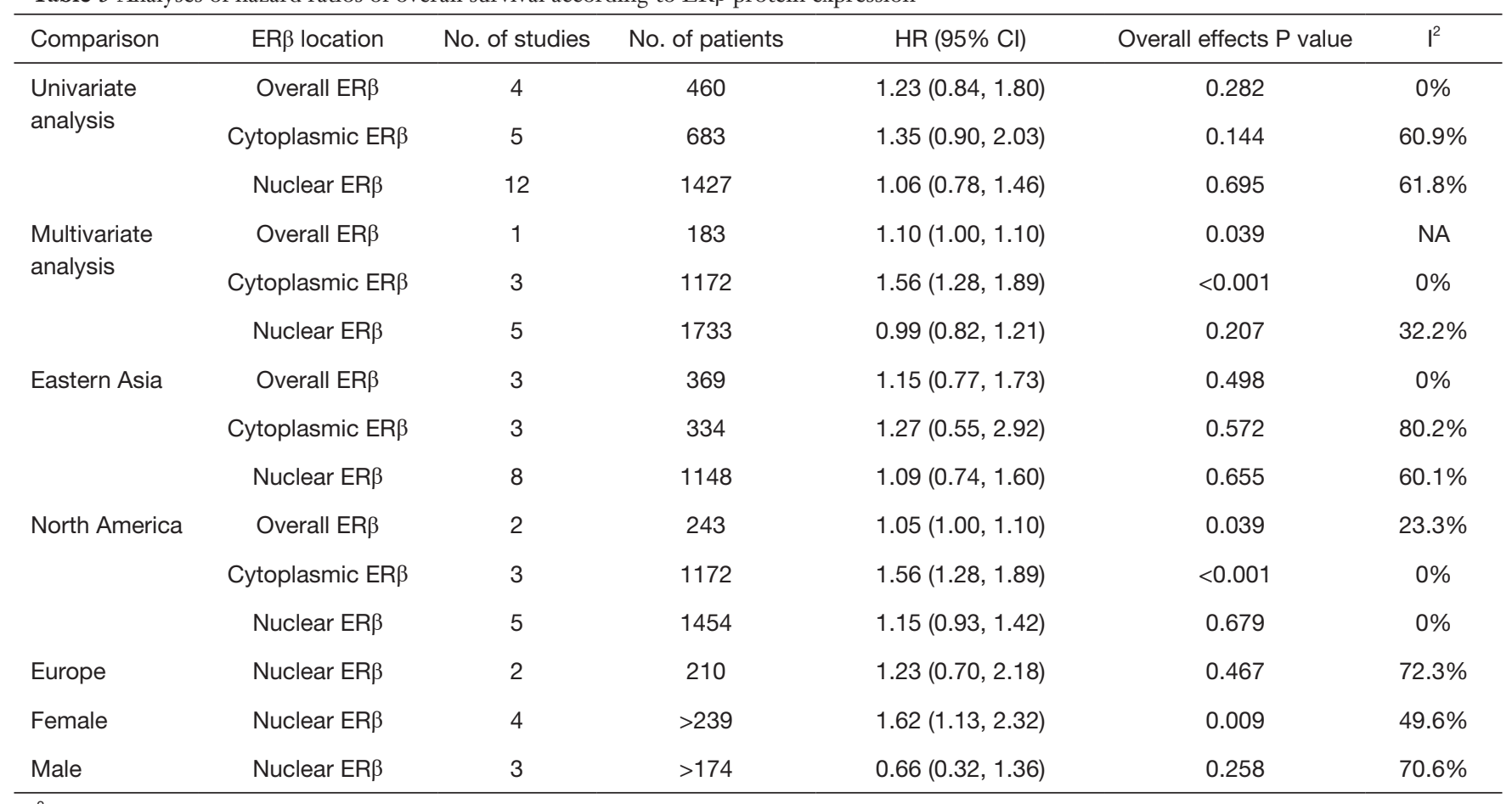

$\mathrm{I}^{2}$ represents the heterogeneity in each group. $\mathrm{ER} \beta$, estrogen receptor beta; $\mathrm{HR}$, hazard ratio; $\mathrm{Cl}$, confidence interval.

the patients are shown in Table 4. Most of the patients were diagnosed with lung adenocarcinoma $(79.5 \%)$ and eight patients were diagnosed with squamous cell lung carcinoma (20.5\%). All of the patients had stage III disease, of which $27(69.2 \%)$ had stage IIIA disease and $12(30.8 \%)$ had stage IIIB disease.

Tissue samples for western blotting and RT-qPCR were obtained from a female patient diagnosed with adenocarcinoma and a male patient diagnosed with squamous cell carcinoma.

\section{ERß expression in tumor and non-tumor tissue}

IHC staining showed that 32 patients $(82.1 \%)$ had high ER $\beta$ expression and seven patients (17.9\%) had low ER $\beta$ expression in the tumor tissues, whereas only nine patients (23.1\%) had high ER $\beta$ expression in the normal adjacent tissues. The mean ER $\beta$ score in the tumor and normal adjacent tissues is 5.72 and 3.69, respectively. Overall, the IHC score of ER $\beta$ protein expression was significantly higher in the tumor tissues than in the normal adjacent tissues $(\mathrm{P}<0.0001)$ (Figure 5).

In the lung adenocarcinoma gene expression profile dataset, 526 cases were tumor tissues (all from TCGALUAD) and 347 cases were normal tissues (288 from GTEx-LUNG and 59 from TCGA-LUAD). ER $\beta$ mRNA expression was not significantly different between tumor tissues and normal tissues (Figure 4C,D; Table S4). To verify the differential expression in the above dataset, four GEO datasets (Table S5) of lung adenocarcinoma were selected. The heatmap drawn from the $\log \mathrm{FC}$ and $\mathrm{p}$-values showed that the relatively stable ER $\beta$ mRNA expression (Figure 4E).

To further validate the inconsistency between ER $\beta$ protein and mRNA expression, we analyzed the protein and mRNA expression in paired clinical tissues from two patients (Figure 5). Consistent with the IHC results, Western blotting of paired tissues from the two patients (Figure 6) also showed that the protein expression of $\mathrm{ER} \beta$ was more prominent in the NSCLC tissues than in the normal adjacent tissues (Figure 6A,C). However, the corresponding ER $\beta$ mRNA expression of one of the two patients showed no significant difference between the cancerous tissues and the normal adjacent tissues; the other patient showed even lower ER $\beta$ mRNA expression in the cancerous tissues than in the normal adjacent tissues (Figure 6B,D). 
A

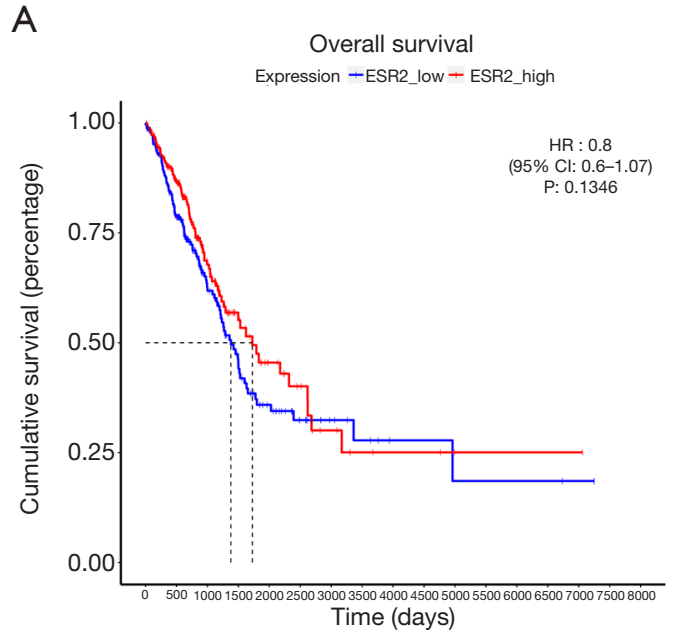

B

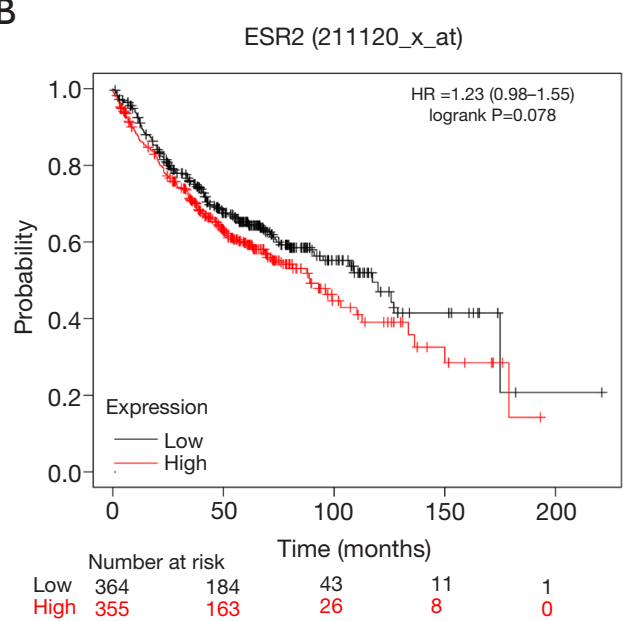

C

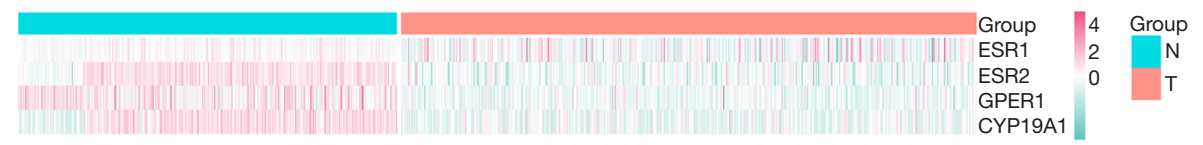

D

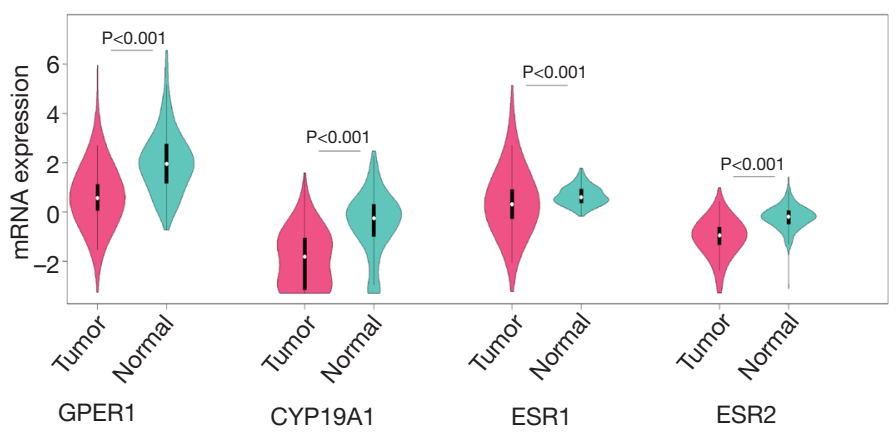

$\mathrm{E}$

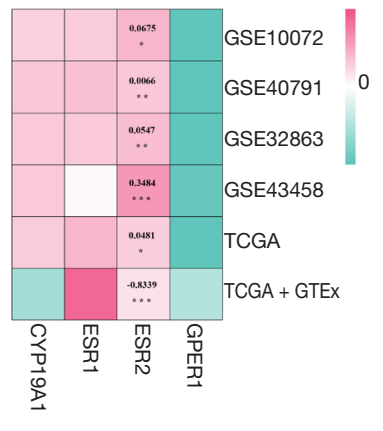

Figure 4 Survival analysis and differential expression analysis from public databases. (A,B) The Kaplan-Meier curves showing associations between ER $\beta$ mRNA expression and overall survival in lung adenocarcinoma. (A) Survival analysis from TCGA-LUAD. (B) Survival analysis from Kaplan-Meier Plotter. (C,D,E) The identification of differentially expressed genes from TCGA-LUAD, GTEx-LUNG, and 4 GEO datasets. (C) Heatmap of differential expression analysis for 4 target genes in the training dataset. (D) Violin plot indicating the expression of 4 target genes between tumor and normal tissues in the training dataset. (E) Heatmap of differential expression analysis for 4 target genes in 4 GEO validation datasets. Every cell representing differentially expressed genes in each dataset is labeled with $\operatorname{logFC}$ value and $\mathrm{P}$ value $\left({ }^{*} \mathrm{P}<0.05,{ }^{* *} \mathrm{P}<0.01,{ }^{* * *} \mathrm{P}<0.001\right)$. ESR2, ER $\beta$, estrogen receptor beta; HR, hazard ratio.

\section{Effect of METTL3 knockdown on ERß expression}

To investigate the possible role of METTL3 in the regulation of ER $\beta$ expression, we measured the protein and mRNA levels of ER $\beta$ after knockdown of METTL3 in the A549 cell line. The validation of the efficiency of siRNA_METTL3 by RT-qPCR and western blotting is shown in Figure 7. Interestingly, we found that knockdown of METTL3 had a minor effect on ER $\beta$ mRNA levels, whereas it resulted in a significant decrease in ER $\beta$ protein levels. These results indicated that METTL 3 might regulate the translation process of ER $\beta$ and cause high ER $\beta$ protein expression level in the presence of low ER $\beta$ mRNA expression level. 
Table 4 Clinicopathological characteristics of NSCLC cases $(n=39)$

\begin{tabular}{lc}
\hline Clinicopathological variables & Patients $(\mathrm{n}=39), \mathrm{n}(\%)$ \\
\hline ER $\beta$ expression in tumor tissue & $32(82.1)$ \\
High & $7(17.9)$ \\
Low & \\
ER $\beta$ expression in normal adjacent & \\
tissue & $9(23.1)$ \\
High & $30(76.9)$ \\
Low & \\
Gender & $23(59.0)$ \\
Male & $16(41.0)$ \\
Female & \\
Histology & $31(79.5)$ \\
Adenocarcinoma & $8(20.5)$ \\
Squamous cell & \\
Stage & $27(69.2)$ \\
IIIA & $12(30.8)$ \\
IIIB &
\end{tabular}

NSCLC, non-small cell lung cancer; ER $\beta$, estrogen receptor beta.

\section{Discussion}

\section{Summary of the main results}

The present systematic review and meta-analysis summarized data from 23 independent studies to clarify the association between ER $\beta$ protein expression and lung cancer survival. We demonstrated that high overall ER $\beta$ and cytoplasmic ER $\beta$ were negatively associated with the OS of NSCLC, and this association was consistent in lung adenocarcinoma. High nuclear ER $\beta$ expression had no effect on NSCLC OS, however, it had a negative effect on OS in lung adenocarcinoma and the female population. Our results conflict with those of two previous meta-analyses $(11,12)$. This conflict may be due to the following reasons. First, we included lung adenocarcinoma-specific studies additional newly published NSCLC studies via a systematic literature search. Second, we excluded studies of ER $\beta$ at the mRNA level to ensure that all of the retrieved studies evaluated ER $\beta$ protein levels. Third, we extracted additional and detailed prognosis information from each study and performed comprehensive analyses using different subcellular localizations. In addition to survival analysis based on protein level, we performed bioinformatics analysis and found that $\mathrm{ER} \beta \mathrm{mRNA}$ was not predictive of lung adenocarcinoma survival, which is consistent with the conclusion of a meta-analysis published in 2015 (14). Therefore, our results revealed that the prognostic value of ER $\beta$ protein and mRNA expression is different.

Public database analysis revealed that ER $\beta$ mRNA was not highly expressed in lung adenocarcinoma tissues, when compared with that in normal lung tissues. Our validation in paired tissues of patients who underwent surgical resection also showed that ER $\beta$ mRNA was not highly expressed in NSCLC. All this evidence from mRNA level is inconsistent with the high $\mathrm{ER} \beta$ protein level in tumor tissues proved by our IHC results and western blotting results from paired tissues of patients. To further explore the possible mechanism of this inconsistency, we knocked down METTL3 in an NSCLC cell line and found that proteinbut not mRNA—expression of ER $\beta$ was downregulated.

We found that ER $\beta$ protein was highly expressed in tumor tissues, when compared with that in non-tumor tissues; however, ER $\beta$ mRNA was undifferentiated. We propose that ER $\beta$ mRNA is regulated by posttranscriptional modifications. Post-transcriptional modification of mRNA regulates protein expression in many tumors (43). For example, Choe et al. reported that mRNA circularization by METTL3-eIF3h enhances translation and promotes oncogenesis (44). Liu et al. reported that $\mathrm{m}^{6} \mathrm{~A}$ methylation regulated CTNNB1 (which encodes $\beta$-catenin) to promote the proliferation of hepatoblastoma (45). Arango et al. reported that $\mathrm{N} 4$-acetylcytidine (ac4C) is an mRNA modification that improves translation efficiency (46). We propose that the aberrant post-translational modification of $\mathrm{m}^{6} \mathrm{~A}$ mediated by METTL3 in NSCLC tissues enhanced the subsequent translation process, which in turn resulted in the inconsistency between ER $\beta$ protein and mRNA levels. Therefore, further studies are required for us to explore the specific mechanism by which METTL3 regulates the expression of ER $\beta$ in NSCLC progression.

The downregulation of ER $\beta$ mRNA in tumor tissues was reported by Read et al. in 1989, in which the estrogen signaling pathway in MCF-7 cells was activated after estrogen stimulation; however, the mRNA level of ER $\beta$ was decreased, which may be a negative feedback regulation (47). Another study reported that, in astrocyte tumors, patients with high E2 levels had low ER $\alpha$ mRNA levels and poor prognosis (48). Therefore, it is possible that the more active the ER signaling pathway, the lower the ER mRNA level.

Further studies are also required for the different effects of nuclear and cytoplasmic ER $\beta$ in NSCLC, particularly 
A

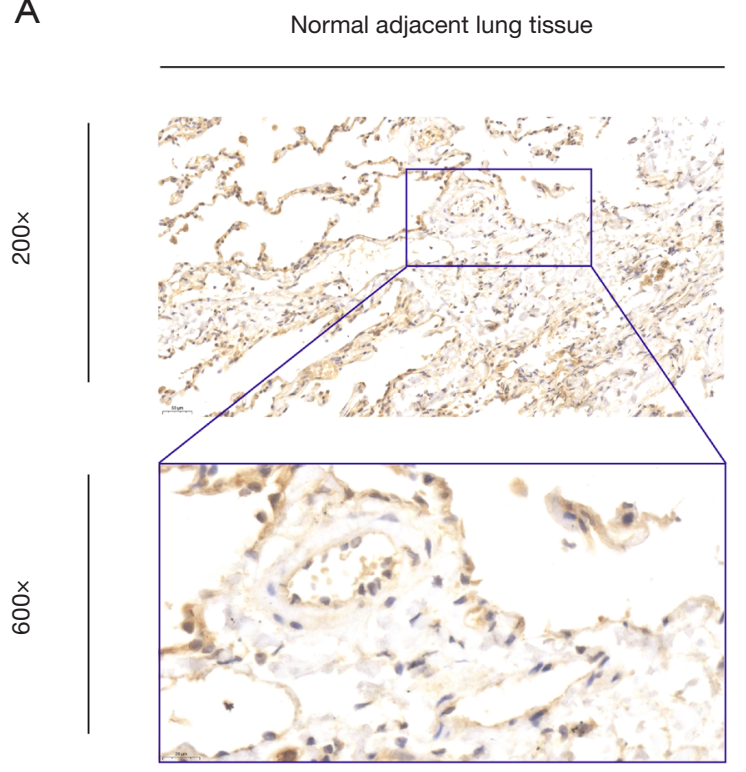

Primary NSCLC

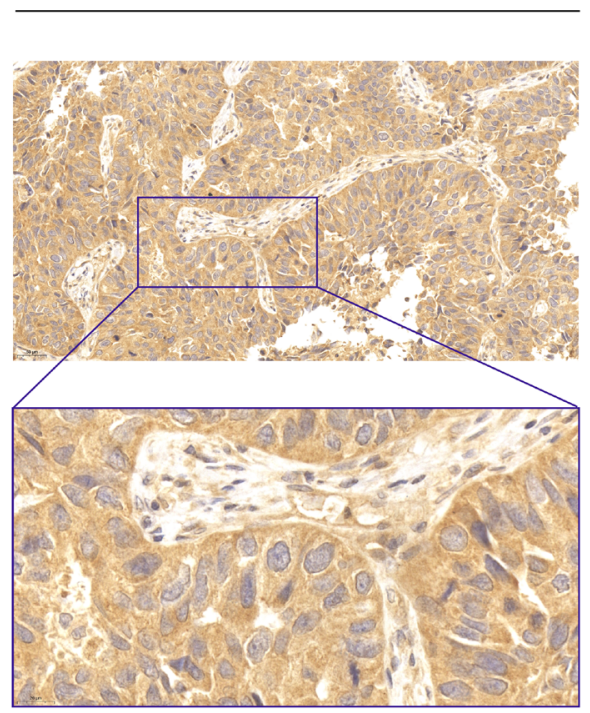

B

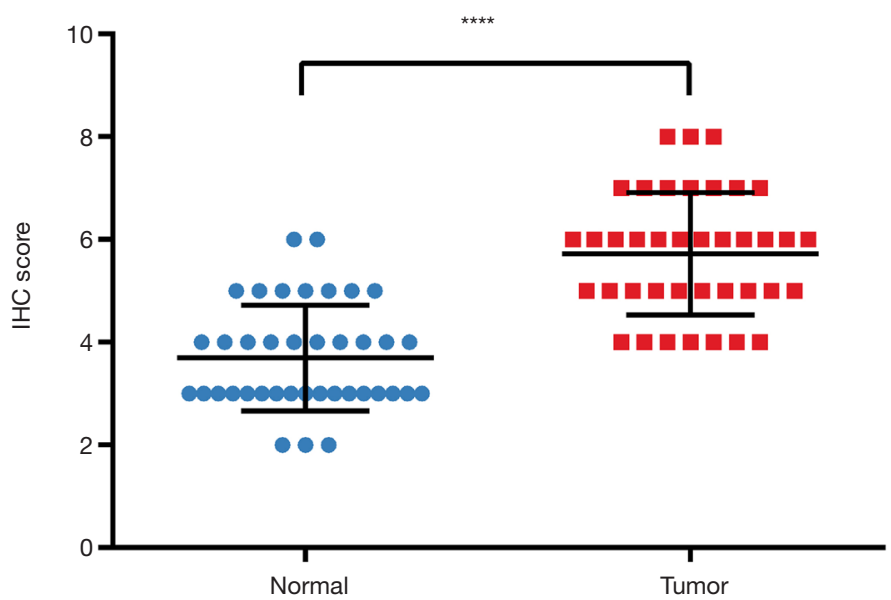

Figure 5 Expression of ER $\beta$ and evaluated via immunohistochemical analyses of primary NSCLC tissue and normal adjacent lung tissue. (A) Representative IHC staining images from paired human primary NSCLC tissue and their normal adjacent lung tissue for ER $\beta$. (B) Quantification data of IHC score for 39 paired primary NSCLC tissues and normal adjacent lung tissues. ${ }^{* * *} \mathrm{P}<0.0001, t$-test. ER $\beta$, estrogen receptor beta; NSCLC, non-small cell lung cancer; IHC, immunohistochemistry.

lung adenocarcinoma. ER $\beta$ of different subcellular localizations exerts its influence via genomic and nongenomic signaling. Zhang et al. reported that mitochondrial ER $\beta$ may be involved in the inhibition of apoptosis by disrupting the interactions of Bad-Bcl-XL and Bad-Bcl2 in NSCLC (49). Our team reported that ER $\beta$ up-regulates the expression of IL- 6 to promote the progression of lung adenocarcinoma (7). ER $\beta$ and insulin-like growth factor 1 synergistically promote the development of lung adenocarcinoma (17). Nuclear ER $\beta$ is a transcription factor in the genomic pathways (50), and it may increase lncRNA-MALAT1 (MALAT1) expression by directly binding to the estrogen response elements located on the promoter of MALAT1 (31), leading to enhanced tumor cell proliferation, invasion, and metastasis and poor prognosis in lung adenocarcinoma patients. However, further research is needed to explain why cytoplasmic ER $\beta$ leads to a poorer prognosis than nuclear ER $\beta$. 
A

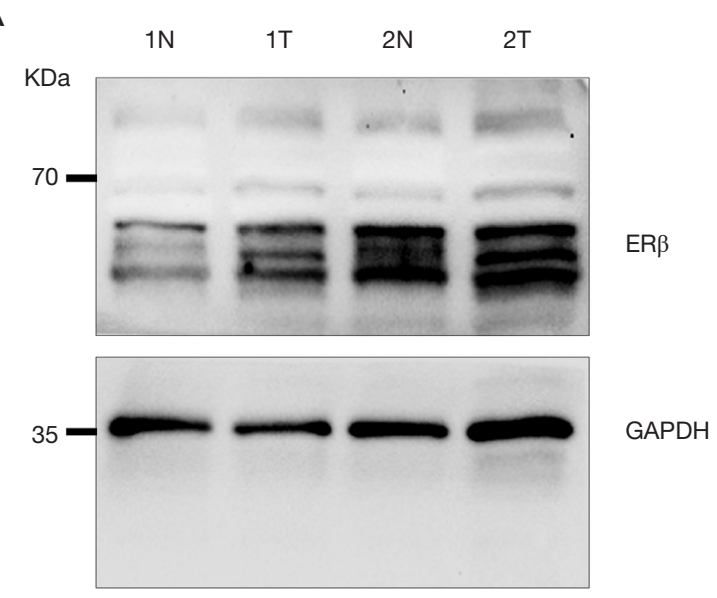

B

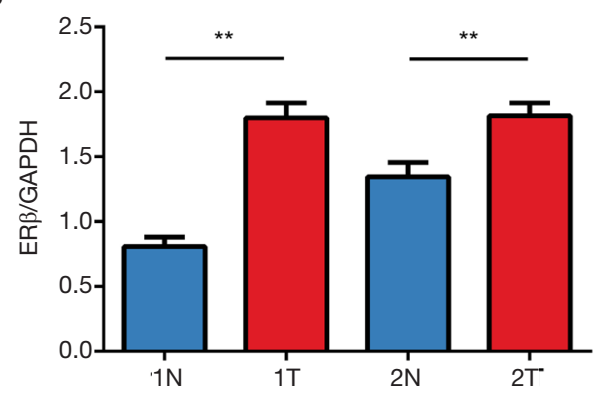

C

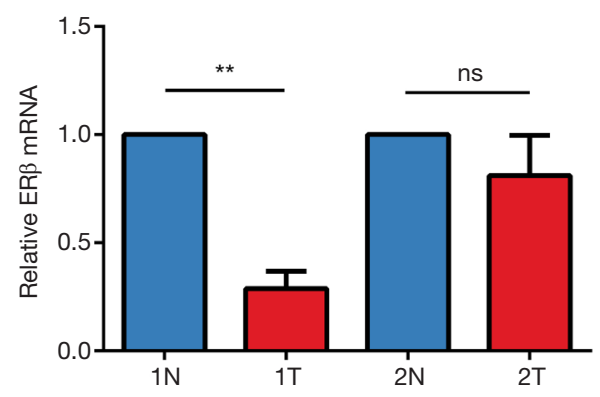

Figure 6 Protein and mRNA expression of ER $\beta$ validated in 2 pairs of NSCLC and normal adjacent samples. (A) ER $\beta$ protein expression examined by western blot. (B) ER $\beta$ mRNA expression examined by RT-qPCR. N, normal adjacent tissue; T, tumor tissue. ${ }^{* *} \mathrm{P}<0.01, \mathrm{~ns}$ indicates no significant differences; $t$-test.

\section{Limitations}

Several limitations of our meta-analysis were noted. The effect sizes in some of the retrieved studies were not available and were estimated from the Kaplan-Meier survival curve. Heterogeneity existed between the study populations of retrieved studies because some studies focused on a female population, high aromatase population or EGFR wild-type population only (29,31,34). Because only five studies mentioned that they used antibodies that only detect ER $\beta 1$ and the other studies did not use ER $\beta$ isoform-specific antibodies (Table S3), this metaanalysis could not distinguish between the five isoforms of ER $\beta$. Finally, the semi-quantitative IHC method relies on the experience of technicians and presents discrepancies between antibodies and cut-off points (Table S3) (51). These limitations may create doubt on the reliability of the summary estimates; however, our results were generally stable.

Considering the differentiation of histological types for the first time, our meta-analysis provides the latest evidence to systematically evaluate the prognostic value of cytoplasmic and nuclear ER $\beta$ in NSCLC. Our bioinformatics analysis provides additional evidence for the limited prognosis data of ER $\beta$ mRNA and proposes a new contradiction that deserves further investigation of the expression of ER $\beta$ at the protein and mRNA levels. Our experiments confirmed the protein and mRNA expression in clinical samples and improved the reliability of this inconsistency. We placed an objective hypothesis on this inconsistency, and conducted a preliminary investigation in lung cancer cell lines, which made the research highly comprehensive. In future studies, we will explore the relationship between the $\mathrm{m} 6 \mathrm{~A}$ modification and the estrogen signaling pathway in NSCLC. In addition, the question of whether METTL3 modification can enhance the translational efficiency of ER $\beta$ in promoting the progression of NSCLC will be elucidated further.

\section{Conclusions}

In conclusion, this study indicated that the high expression of ER $\beta$ protein was associated with poor outcomes in NSCLC, particularly lung adenocarcinoma, and that ER $\beta$ mRNA expression had no evident effect on lung adenocarcinoma survival. ER $\beta$ protein is highly expressed in NSCLC tissues, whereas ER $\beta$ mRNA is not. The METTL3- $\mathrm{m}^{6} \mathrm{~A}$ module might regulate the process of ER $\beta$ translation and cause NSCLC progression. Our results contribute to the evaluation of prognosis and clinical decisions for NSCLC. Further biological experiments are required to elucidate the specific mechanism underlying the role of $\mathrm{m}^{6} \mathrm{~A}$ modification of ER $\beta$ in NSCLC. 
A
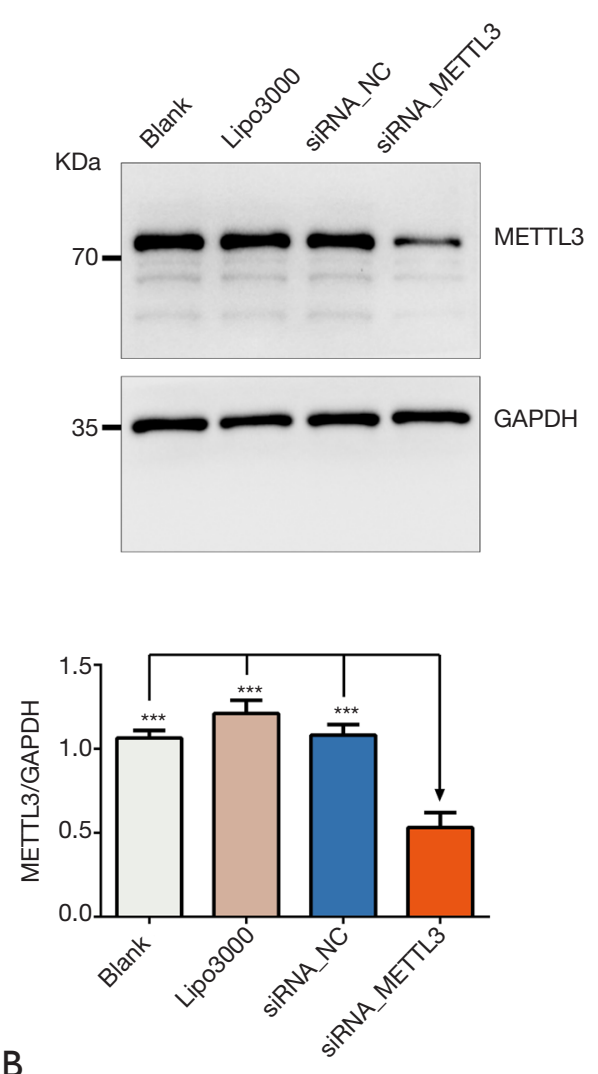

B

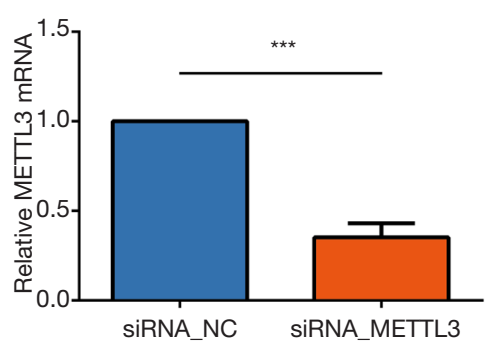

C
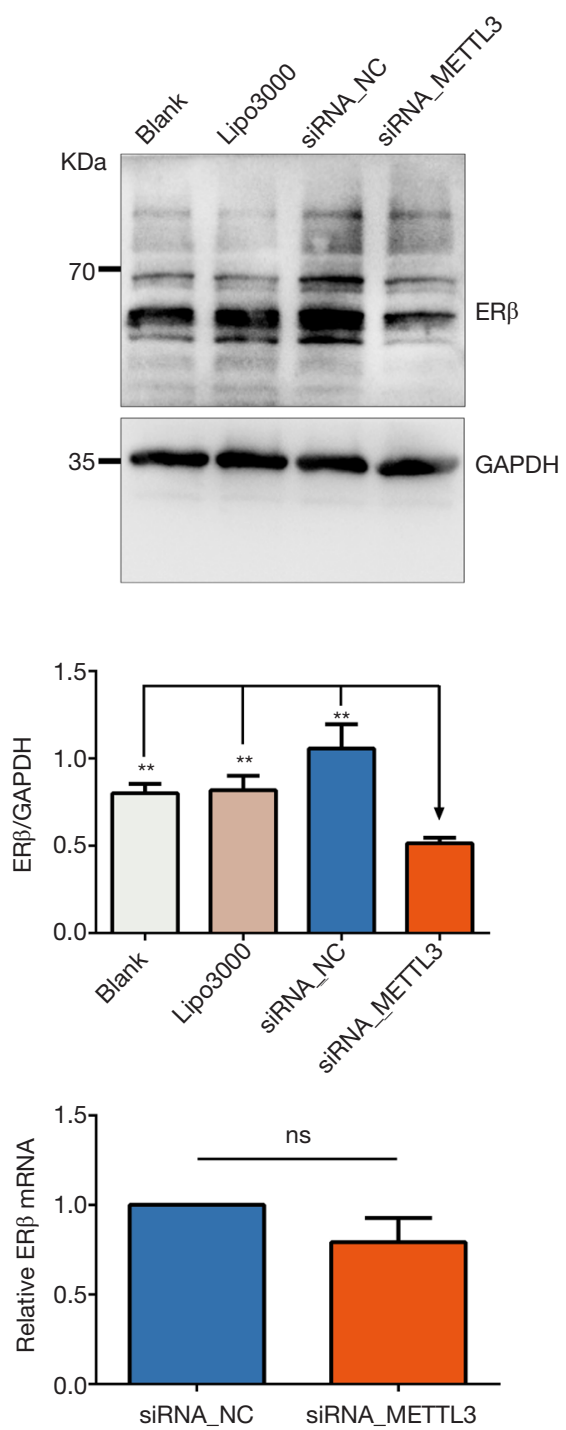

Figure 7 Expression of METTL3 and ER $\beta$ after METTL3 knockdown in A549 cells. (A) Verification of METTL3 knockdown by western blot. (B) Verification of METTL3 knockdown by RT-qPCR (C) Western blot was used to detect ER $\beta$ protein level after METTL3 knockdown. (D) RT-qPCR was used to detect ER $\beta$ mRNA level after METTL3 knockdown. ${ }^{* *} \mathrm{P}<0.01,{ }^{* * *} \mathrm{P}<0.001$, ns indicates no significant differences; $t$-test.

\section{Acknowledgments}

We thank professor Shiyi Cao from School of Public Health, Tongji Medical College for the support in methodology of meta-analysis, and we thank all the patients and clinical investigators who were involved in the studies and datasets selected in this article.

Funding: This work was supported by the National Natural
Science Foundation of China (NSFC) (No. 82072593).

\section{Footnote}

Reporting Checklist: The authors have completed the PRISMA reporting checklist. Available at https://dx.doi. org/10.21037/jtd-21-658 
Peer Review File: Available at https://dx.doi.org/10.21037/ jtd-21-658

Conflicts of Interest: All authors have completed the ICMJE uniform disclosure form (available at https://dx.doi. org/10.21037/jtd-21-658). The authors have no conflicts of interest to declare.

Ethical Statement: The authors are accountable for all aspects of the work in ensuring that questions related to the accuracy or integrity of any part of the work are appropriately investigated and resolved. The study was approved by the Ethics or Institutional Review Board of Union Hospital, Tongji Medical College, Huazhong University of Science and Technology, and written informed consent was obtained from all subjects in accordance with the Declaration of Helsinki (as revised in 2013).

Open Access Statement: This is an Open Access article distributed in accordance with the Creative Commons Attribution-NonCommercial-NoDerivs 4.0 International License (CC BY-NC-ND 4.0), which permits the noncommercial replication and distribution of the article with the strict proviso that no changes or edits are made and the original work is properly cited (including links to both the formal publication through the relevant DOI and the license). See: https://creativecommons.org/licenses/by-nc-nd/4.0/.

\section{References}

1. Kuiper GG, Enmark E, Pelto-Huikko M, et al. Cloning of a novel receptor expressed in rat prostate and ovary. Proc Natl Acad Sci U S A 1996;93:5925-30.

2. Stabile LP, Dacic S, Land SR, et al. Combined analysis of estrogen receptor beta-1 and progesterone receptor expression identifies lung cancer patients with poor outcome. Clin Cancer Res 2011;17:154-64.

3. Tang H, Liao Y, Zhang C, et al. Fulvestrant-mediated inhibition of estrogen receptor signaling slows lung cancer progression. Oncol Res 2014;22:13-20.

4. Liu J, Nie Z, Lei Y, et al. The expression of ERß2, Bcl-xl and Bax in non-small cell lung cancer and associated with prognosis. Int J Clin Exp Pathol 2017;10:10040-6.

5. Hsu LH, Chu NM, Kao SH. Estrogen, Estrogen Receptor and Lung Cancer. Int J Mol Sci 2017;18:1713.

6. Baik CS, Eaton KD. Estrogen signaling in lung cancer: an opportunity for novel therapy. Cancers (Basel) 2012;4:969-88.
7. Huang $\mathrm{Q}$, Zhang $\mathrm{Z}$, Liao $\mathrm{Y}$, et al. $17 \beta$-estradiol upregulates IL6 expression through the ER $\beta$ pathway to promote lung adenocarcinoma progression. J Exp Clin Cancer Res 2018;37:133.

8. Fan S, Liao Y, Qiu W, et al. Estrogen promotes the metastasis of non-small cell lung cancer via estrogen receptor $\beta$ by upregulation of Toll-like receptor 4 and activation of the myd88/NF- $\mathrm{BB} / \mathrm{MMP} 2$ pathway. Oncol Rep 2020. [Epub ahead of print]. doi: 10.3892/or.2020.7574.

9. Wu CT, Chang YL, Shih JY, et al. The significance of estrogen receptor beta in 301 surgically treated nonsmall cell lung cancers. J Thorac Cardiovasc Surg 2005;130:979-86.

10. Cheng TD, Darke AK, Redman MW, et al. Smoking, Sex, and Non-Small Cell Lung Cancer: Steroid Hormone Receptors in Tumor Tissue (S0424). J Natl Cancer Inst 2018;110:734-42.

11. Luo Z, Wu R, Jiang Y, et al. Overexpression of estrogen receptor beta is a prognostic marker in non-small cell lung cancer: a meta-analysis. Int J Clin Exp Med 2015;8:8686-97.

12. Ma L, Zhan P, Liu Y, et al. Prognostic value of the expression of estrogen receptor $\beta$ in patients with nonsmall cell lung cancer: a meta-analysis. Transl Lung Cancer Res 2016;5:202-7.

13. Aresti U, Carrera S, Iruarrizaga E, et al. Estrogen receptor 1 gene expression and its combination with estrogen receptor 2 or aromatase expression predicts survival in non-small cell lung cancer. PLoS One 2014;9:e109659.

14. Li W, Tse LA, Wang F. Prognostic value of estrogen receptors mRNA expression in non-small cell lung cancer: A systematic review and meta-analysis. Steroids 2015;104:129-36.

15. Yang Y, Fan X, Mao M, et al. Extensive translation of circular RNAs driven by N6-methyladenosine. Cell Res 2017;27:626-41.

16. Lin S, Choe J, Du P, et al. The m(6)A Methyltransferase METTL3 Promotes Translation in Human Cancer Cells. Mol Cell 2016;62:335-45.

17. Tang H, Liao Y, Xu L, et al. Estrogen and insulin-like growth factor 1 synergistically promote the development of lung adenocarcinoma in mice. Int J Cancer 2013;133:2473-82.

18. Liu C, Liao Y, Fan S, et al. G-Protein-Coupled Estrogen Receptor Antagonist G15 Decreases Estrogen-Induced Development of Non-Small Cell Lung Cancer. Oncol Res 2019;27:283-92.

19. Fu S, Liu C, Huang Q, et al. Estrogen receptor $\beta 1$ 
activation accelerates resistance to epidermal growth factor receptor-tyrosine kinase inhibitors in non-small cell lung cancer. Oncol Rep 2018;39:1313-21.

20. Page MJ, McKenzie JE, Bossuyt PM, et al. The PRISMA 2020 statement: An updated guideline for reporting systematic reviews. J Clin Epidemiol 2021;134:178-89.

21. Wells GA SB, O'Connell D. The Newcastle-Ottawa scale (NOS) for assessing the quality of nonrandomised studies in meta-analyses. Available online: http://www.ohri.ca/ programs/clinical_epidemiology/oxford.asp

22. Parmar MK, Torri V, Stewart L. Extracting summary statistics to perform meta-analyses of the published literature for survival endpoints. Stat Med 1998;17:2815-34.

23. Kawai H, Ishii A, Washiya K, et al. Estrogen receptor alpha and beta are prognostic factors in non-small cell lung cancer. Clin Cancer Res 2005;11:5084-9.

24. Nose N, Sugio K, Oyama T, et al. Association between estrogen receptor-beta expression and epidermal growth factor receptor mutation in the postoperative prognosis of adenocarcinoma of the lung. J Clin Oncol 2009;27:411-7.

25. Ding X, Li L, Tang C, et al. Cytoplasmic expression of estrogen receptor $\beta$ may predict poor outcome of EGFRTKI therapy in metastatic lung adenocarcinoma. Oncol Lett 2018;16:2382-90.

26. Lee JH, Kim HK, Shin BK. Expression of female sex hormone receptors and its relation to clinicopathological characteristics and prognosis of lung adenocarcinoma. J Pathol Transl Med 2020;54:103-11.

27. Nose N, Uramoto H, Iwata T, et al. Expression of estrogen receptor beta predicts a clinical response and longer progression-free survival after treatment with EGFR-TKI for adenocarcinoma of the lung. Lung Cancer 2011;71:350-5.

28. Schwartz AG, Prysak GM, Murphy V, et al. Nuclear estrogen receptor beta in lung cancer: expression and survival differences by sex. Clin Cancer Res 2005;11:7280-7.

29. Tanaka K, Shimizu K, Kakegawa S, et al. Prognostic significance of aromatase and estrogen receptor beta expression in EGFR wild-type lung adenocarcinoma. Am J Transl Res 2016;8:81-97.

30. Toh CK, Ahmad B, Soong R, et al. Correlation between epidermal growth factor receptor mutations and expression of female hormone receptors in East-Asian lung adenocarcinomas. J Thorac Oncol 2010;5:17-22.

31. Yu W, Ding J, He M, et al. Estrogen receptor $\beta$ promotes the vasculogenic mimicry (VM) and cell invasion via altering the lncRNA-MALAT1/miR-145-5p/NEDD9 signals in lung cancer. Oncogene 2019;38:1225-38.

32. He C, He Y, Luo H, et al. Cytoplasmic ER 1 expression is associated with survival of patients with Stage IV lung adenocarcinoma and an EGFR mutation at exon 21 L858R subsequent to treatment with EGFR-TKIs. Oncol Lett 2019;18:792-803.

33. He YF, Luo HQ, Wang W, et al. Clinical features and prognosis-associated factors of non-small cell lung cancer exhibiting symptoms of bone metastasis at the time of diagnosis. Oncol Lett 2015;9:2706-12.

34. Mah V, Marquez D, Alavi M, et al. Expression levels of estrogen receptor beta in conjunction with aromatase predict survival in non-small cell lung cancer. Lung Cancer 2011;74:318-25.

35. Verma MK, Miki Y, Abe K, et al. Cytoplasmic estrogen receptor $\beta$ as a potential marker in human non-small cell lung carcinoma. Expert Opin Ther Targets 2012;16 Suppl 1:S91-102.

36. Mauro LV, Dalurzo M, Carlini MJ, et al. Estrogen receptor $\beta$ and epidermal growth factor receptor as earlystage prognostic biomarkers of non-small cell lung cancer. Oncol Rep 2010;24:1331-8.

37. Monica V, Longo M, Felice B, et al. Role of hormone receptor expression in patients with advanced-stage lung cancer treated with chemotherapy. Clin Lung Cancer 2012;13:416-23.

38. Navaratnam S, Skliris G, Qing G, et al. Differential role of estrogen receptor beta in early versus metastatic non-small cell lung cancer. Horm Cancer 2012;3:93-100.

39. Skov BG, Fischer BM, Pappot H. Oestrogen receptor beta over expression in males with non-small cell lung cancer is associated with better survival. Lung Cancer 2008;59:88-94.

40. Verma MK, Miki Y, Abe K, et al. Co-expression of estrogen receptor beta and aromatase in Japanese lung cancer patients: gender-dependent clinical outcome. Life Sci 2012;91:800-8.

41. Gao X, Cai Y, Wang Z, et al. Estrogen receptors promote NSCLC progression by modulating the membrane receptor signaling network: a systems biology perspective. J Transl Med 2019;17:308.

42. Enwere EK, Dean ML, Li H, et al. The prevalence and prognostic significance of estrogen receptor beta expression in non-small cell lung cancer. Transl Lung Cancer Res 2020;9:496-506.

43. Zhang $\mathrm{C}$, Huang S, Zhuang $\mathrm{H}$, et al. Y'THDF2 promotes the liver cancer stem cell phenotype and cancer 
metastasis by regulating OCT4 expression via m6A RNA methylation. Oncogene 2020;39:4507-18.

44. Choe J, Lin S, Zhang W, et al. mRNA circularization by METTL3-eIF3h enhances translation and promotes oncogenesis. Nature 2018;561:556-60.

45. Liu L, Wang J, Sun G, et al. m6A mRNA methylation regulates CTNNB1 to promote the proliferation of hepatoblastoma. Mol Cancer 2019;18:188.

46. Arango D, Sturgill D, Alhusaini N, et al. Acetylation of Cytidine in mRNA Promotes Translation Efficiency. Cell 2018;175:1872-1886.e24.

47. Read LD, Greene GL, Katzenellenbogen BS. Regulation of estrogen receptor messenger ribonucleic acid and protein levels in human breast cancer cell lines by sex steroid hormones, their antagonists, and growth factors. Mol Endocrinol 1989;3:295-304.

48. Dueñas Jiménez JM, Candanedo Arellano A, Santerre

Cite this article as: Meng W, Liao Y, Chen J, Wang Y, Meng Y, Li K, Xiao H. Upregulation of estrogen receptor beta protein but not mRNA predicts poor prognosis and may be associated with enhanced translation in non-small cell lung cancer: a systematic review and meta-analysis. J Thorac Dis 2021;13(7):42814300. doi: $10.21037 /$ jtd-21-658
A, et al. Aromatase and estrogen receptor alpha mRNA expression as prognostic biomarkers in patients with astrocytomas. J Neurooncol 2014;119:275-84.

49. Zhang G, Yanamala N, Lathrop KL, et al. Ligandindependent antiapoptotic function of estrogen receptor-beta in lung cancer cells. Mol Endocrinol 2010;24:1737-47.

50. Hershberger PA, Stabile LP, Kanterewicz B, et al. Estrogen receptor beta (ERbeta) subtype-specific ligands increase transcription, $\mathrm{p} 44 / \mathrm{p} 42$ mitogen activated protein kinase (MAPK) activation and growth in human nonsmall cell lung cancer cells. J Steroid Biochem Mol Biol 2009;116:102-9.

51. Atmaca A, Al-Batran SE, Wirtz RM, et al. The validation of estrogen receptor $1 \mathrm{mRNA}$ expression as a predictor of outcome in patients with metastatic non-small cell lung cancer. Int J Cancer 2014;134:2314-21. 
Supplementary

Table S1 Search strategy

\begin{tabular}{ll}
\hline Database & Strategy \\
\hline PubMed & (lung cancer[Title/Abstract]) OR (lung adenocarcinoma[Title/Abstract]) OR (adenocarcinoma of lung[Title/Abstract]) \\
& OR (NSCLC[Title/Abstract]) OR (lung neoplasms[Title/Abstract]) OR (lung tumor[Title/Abstract])) AND ((estrogen \\
& receptor[Title/Abstract]) OR (oestrogen receptor[Title/Abstract]) OR (oestrogen[Title/Abstract]) OR (estrogen receptor \\
& $\beta[$ Title/Abstract]) OR (ER $[$ [Title/Abstract]) OR (estrogen[Title/Abstract]) OR (ERbeta[Title/Abstract])) \\
Web of Science & (TS=(lung cancer) OR TS=(lung adenocarcinoma) OR TS=(adenocarcinoma of lung) OR TS=(NSCLC) OR TS=(lung \\
& neoplasms) OR TS=(Non Small Cell Lung Carcinoma) OR TS=(lung tumor)) AND (TS=(estrogen) OR TS=(estrogen \\
& receptor) OR TS=(estrogen receptor $\beta$ ) OR TS=(oestrogen receptor) OR TS=(oestrogen) OR TS=(ERbeta) OR TS=(ER $\beta))$ \\
& AND (ALL=(survival) OR ALL=(overall survival) OR ALL=(outcome) OR ALL=(prognosis) OR ALL=(prognostic)) \\
& ((estrogen receptor beta) or (ERbeta) or (estrogen receptor) or (estrogen) or (oestrogen receptor) or (oestrogen)). \\
& ab. AND (lung cancer) or (lung adenocarcinoma) or (adenocarcinoma of lung) or (lung neoplasms) or (lung tumor) or \\
& (NSCLC)).ab.
\end{tabular}

Table S2 Summary of primers used in this study

\begin{tabular}{|c|c|c|c|c|c|c|c|}
\hline Gene description & Species & $\begin{array}{l}\text { Primer bank } \\
\text { ID }\end{array}$ & $\begin{array}{l}\text { NCBI } \\
\text { gene ID }\end{array}$ & Sequence $\left(5^{\prime}-3^{\prime}\right)$ & Length & $\mathrm{Tm}$ & Location \\
\hline ESR2 & Human & 333609292c1 & 2100 & Forward primer: AGCACGGCTCCATATACATACC & 22 & 61.4 & $77-98$ \\
\hline GAPDH & Human & $378404907 c 1$ & 2597 & Forward primer: GGAGCGAGATCCСTCCAAAAT & 21 & 61.6 & $108-128$ \\
\hline
\end{tabular}

ESR2, ER $\beta$, estrogen receptor beta; GAPDH, glyceraldehyde-3-phosphate dehydrogenase. 
Table S3 Summary of included studies and characteristics of patients

\begin{tabular}{|c|c|c|c|c|c|c|c|c|c|}
\hline Author (year) & $\begin{array}{l}\text { Time of patients } \\
\text { diagnosed }\end{array}$ & Study design & $\begin{array}{l}\text { Female } \\
(\%)\end{array}$ & $\begin{array}{l}\text { EGFR mutation/ } \\
\text { expression (\%) }\end{array}$ & $\begin{array}{l}\text { Aromatase+ } \\
(\%)\end{array}$ & $\begin{array}{l}\text { Adenocarcinoma } \\
(\%)\end{array}$ & ER $\beta$ antibody & $\begin{array}{l}\text { ER } \beta \text { positive cut-off } \\
\text { definition }\end{array}$ & Covariate adjustment \\
\hline Kawai 2005 & $1995-1997$ & $\begin{array}{l}\text { Retrospective } \\
\text { cohort study }\end{array}$ & 42.4 & NR & NR & 77.3 & $\begin{array}{l}\text { H-150, Santa Cruz } \\
\text { Biotechnology, 1:100 dilution in } \\
\text { PBS }\end{array}$ & $\begin{array}{l}\text { The proportion and } \\
\text { intensity scores for total } \\
\text { score, score } 2-8\end{array}$ & NR \\
\hline Schwarz 2005 & 1990-2004 & $\begin{array}{l}\text { Retrospective } \\
\text { cohort study }\end{array}$ & NR & NR & NR & 100 & $\begin{array}{l}\text { Mouse anti-ER } \beta-1 \text { monoclonal } \\
\text { antibody-MCA1974S (Serotec, } \\
\text { Oxford, United Kingdom) }\end{array}$ & $\begin{array}{l}\text { Samples with at least weak } \\
\text { (1+) staining in } \geq 10 \% \text { of } \\
\text { tumor cells }\end{array}$ & $\begin{array}{l}\text { Sex, race, age at } \\
\text { diagnosis, stage at } \\
\text { diagnosis, smoking status, } \\
\text { pack-years, history of } \\
\text { tuberculosis, and histology }\end{array}$ \\
\hline Wu 2005 & $1990-2001$ & $\begin{array}{l}\text { Retrospective } \\
\text { cohort study }\end{array}$ & 42.2 & NR & NR & 64.5 & BioGenex, 1:100 & $\begin{array}{l}\text { Moderate-to-strong nuclear } \\
\text { staining of more than } 50 \% \\
\text { of the neoplastic cells }\end{array}$ & $\begin{array}{l}\text { Stage of tumor, } \\
\text { differentiation, smoking } \\
\text { status, state of vascular } \\
\text { invasion }\end{array}$ \\
\hline Skov 2008 & 1989-1992 & $\begin{array}{l}\text { Retrospective } \\
\text { cohort study }\end{array}$ & 31.7 & NR & NR & 38.5 & $\begin{array}{l}\text { Oestrogen Receptor Clone } \\
\text { PPG5/10, Code M7292, Dako } \\
\text { Cytomation, Denmark }\end{array}$ & $\begin{array}{l}\text { At least weak staining in } \\
\text { more than } 10 \% \text { tumor cells }\end{array}$ & $\begin{array}{l}\text { Gender, age, stage at } \\
\text { diagnosis and histology }\end{array}$ \\
\hline Toh 2010 & 1999-2002 & $\begin{array}{l}\text { Retrospective } \\
\text { cohort study }\end{array}$ & 40.6 & $39 / 61$ & NR & 100 & $\begin{array}{l}\text { Oestrogen Receptor Clone } \\
\text { PPG5/10, Dako Cytomation, } \\
\text { Denmark 1:100 }\end{array}$ & $\begin{array}{l}\text { At least one }+ \text { staining in } \\
\geq 10 \% \text { of tumor cells }\end{array}$ & NR \\
\hline Mauro 2010 & $1997-2004$ & $\begin{array}{l}\text { Retrospective } \\
\text { cohort study }\end{array}$ & 31.6 & $36 / 58^{*}$ & NR & 31.6 & Chicken polyclonal antibody & $\geq 5 \%$ tumor cells positive & NR \\
\hline Nose 2011 & 2004-2009 & $\begin{array}{l}\text { Retrospective } \\
\text { cohort study }\end{array}$ & 46.5 & $30 / 13$ & NR & 100 & $\begin{array}{l}\text { H-150 (Biotechnology, Santa } \\
\text { Cruz, CA) diluted 1:10 }\end{array}$ & $5-8$ score & NR \\
\hline Mah 2011 & NR & $\begin{array}{l}\text { Retrospective } \\
\text { cohort study }\end{array}$ & NR/NR & NR & $60 / 0 ; 190 / 0$ & NR & $\begin{array}{l}\text { Mouse anti-ER } \beta-1 \text { monoclonal } \\
\text { antibody (clone PPG5/10, } \\
\text { product \#MCA1974ST, } \\
\text { AbDSerotec, Raleigh, NC) }\end{array}$ & $\begin{array}{l}{[(3 x)+(2 y)+(1 z)] / 100} \\
\text { where } x, y, \text { and } z \text { are } \% \\
\text { staining at intensity } 3,2 \text {, } \\
\text { and } 1 \text {, respectively; } 57 \text { th } \\
\text { percentile for overall } \operatorname{Er} \beta \\
\text { higher than median levels } \\
\text { for cytoplasmic ER } \beta\end{array}$ & $\begin{array}{l}\text { (Cytoplasmic ER } \beta \text { ) stage, } \\
\text { age, and grade }\end{array}$ \\
\hline Stabile 2011 & 1992-2006 & Cohort study & 49.7 & $55 / 120^{*}$ & $56 / 123$ & 59 & $\begin{array}{l}\text { Mouse anti-ER } \beta-1 \text { monoclonal } \\
\text { antibody MCA1974ST, AbD } \\
\text { Serotec, Raleigh, NC }\end{array}$ & $\begin{array}{l}\text { Score }>7 \text { for cytoplasmic } \\
\text { ER } \beta \text { and total ER } \beta\end{array}$ & $\begin{array}{l}\text { Age, tumor stage, sex, } \\
\text { smoking status }\end{array}$ \\
\hline Monica 2012 & 2008-2010 & $\begin{array}{l}\text { Retrospective } \\
\text { cohort study }\end{array}$ & 25.5 & NR & NR & 53.8 & $\begin{array}{l}\text { mouse anti-ER } \beta \text { (clone PPG5/10, } \\
\text { Dako), dilution, 1:50 }\end{array}$ & $8-12$ score & NR \\
\hline Navaratnam 2012 & $\begin{array}{l}1999 / 2000- \\
2002\end{array}$ & $\begin{array}{l}\text { Retrospective } \\
\text { cohort study/ } \\
\text { retrospective } \\
\text { cohort study }\end{array}$ & $59.5 / \mathrm{NR}$ & NR & NR & NR & $\begin{array}{l}\text { monoclonal, 14C8, Genetex, TX, } \\
\text { USA }\end{array}$ & $\geq$ median IHC score & NR \\
\hline Verma(1)2012 & NR & $\begin{array}{l}\text { Retrospective } \\
\text { cohort study }\end{array}$ & 39.5 & NR & $140 / 22$ & 74.1 & $\begin{array}{l}\text { clone 14C8; GeneTex Inc., San } \\
\text { Antonio, TX, 1:50 }\end{array}$ & $\geq 10 \%$ tumour cells positive & NR \\
\hline Verma(2)2012 & $1993-2003$ & $\begin{array}{l}\text { Retrospective } \\
\text { cohort study }\end{array}$ & 39.1 & NR & $146 / 23$ & 76.3 & $\begin{array}{l}\text { clone 14C8; GeneTex Inc., San } \\
\text { Antonio, TX, 1:50 }\end{array}$ & $\geq 10 \%$ positive results & NR \\
\hline He 2015 & 2010-2012 & $\begin{array}{l}\text { Retrospective } \\
\text { cohort study }\end{array}$ & 32.6 & NR & NR & 71.7 & $\begin{array}{l}\text { from Beijing Bioss Biosynthesis } \\
\text { Biotechnology Co., Ltd., (Beijing, } \\
\text { China) }\end{array}$ & NR & NR \\
\hline Tanaka 2016 & 2004-2008 & $\begin{array}{l}\text { Retrospective } \\
\text { cohort study }\end{array}$ & 48.7 & $0 / 78$ & $35 / 43$ & 100 & $\begin{array}{l}\text { clone14C8 GeneTex, CA, USA, } \\
1: 200\end{array}$ & Score $1+/ 2+/ 3+$ & NR \\
\hline Gao 2017 & 2004-2009 & $\begin{array}{l}\text { Retrospective } \\
\text { cohort study }\end{array}$ & NR & $27 / 35$ & NR & NR & $\begin{array}{l}\text { ER } \beta \text { (B-1) Santa Cruz sc-390243 } \\
\text { 1:500 }\end{array}$ & $\geq$ median value of score & NR \\
\hline Ding 2018 & 2011-2016 & $\begin{array}{l}\text { Retrospective } \\
\text { cohort study }\end{array}$ & 55.6 & $64 / 62$ & NR & 100 & $\begin{array}{l}\text { mouse monoclonal antibody } \\
\text { 14C8 (cat.no.ab288; Abcam, } \\
\text { Cambridge, UK) 1:100 }\end{array}$ & $\begin{array}{l}>10 \% \text { of tumor cells } \\
\text { exhibited specific, positive } \\
\text { staining in the nucleus or } \\
\text { cytoplasm with at least } 1+ \\
\text { staining }\end{array}$ & NR \\
\hline Yu 2018 & 2011-2013 & $\begin{array}{l}\text { Retrospective } \\
\text { cohort study }\end{array}$ & 100 & NR & NR & 100 & Abcam 288\#14C8 & NR & NR \\
\hline Cheng 2018 & $\begin{array}{l}\text { 2005-2011, } \\
\text { Cohort }\end{array}$ & $\begin{array}{l}\text { Retrospective } \\
\text { cohort study }\end{array}$ & 55.4 & NR & NR & 57.2 & $\begin{array}{l}\text { PPG5/10 (ERB-1 isoform } \\
\text { specific) AbD Serotec. } \\
\text { MCA1974ST }\end{array}$ & $\begin{array}{l}\text { Quartile } 4 \text { vs. } 1 \text { of formula } \\
1 \times(\% \text { cells } 1+)+2 \times(\% \text { cells } \\
2+)+3 \times(\% \text { cells } 3+) \text { with } \\
\text { the weighted average of } \\
\text { percent positivity values }\end{array}$ & $\begin{array}{l}\text { Age, race, sex, smoking } \\
\text { status, histology, and } \\
\text { tumor stage }\end{array}$ \\
\hline He 2019 & $2012-2014$ & $\begin{array}{l}\text { Retrospective } \\
\text { cohort study }\end{array}$ & 72.1 & $122 / 79$ & NR & 100 & $\begin{array}{l}\text { Mouse monoclonal anti-human } \\
\text { ERß1 antibody PPG5/10 (cat.no. } \\
\text { M7292; Dako) 1:50 }\end{array}$ & $\begin{array}{l}\text { Total Er } \beta \text { : score }>9 \text { nuclear } \\
\text { ER } \beta \text { : score }>6\end{array}$ & NR \\
\hline Lee 2020 & 2010-2012 & $\begin{array}{l}\text { Retrospective } \\
\text { cohort study }\end{array}$ & 48.8 & $81 / 3^{*}$ & NR & 100 & $\begin{array}{l}\text { Clone } 14 C 8, \text { Abcam, } \\
\text { Cambridge, UK 1:100 }\end{array}$ & Score 3-8 & NR \\
\hline Enwere & $2003-2006$ & $\begin{array}{l}\text { Retrospective } \\
\text { cohort study }\end{array}$ & 49.8 & NR & NR & 54.2 & $\begin{array}{l}\text { mouse monoclonal, clone } \\
\text { PPG5/10, 1:500, Abcam, } \\
\text { Cambridge, MA, USA) }\end{array}$ & HALO score & $\begin{array}{l}\text { Stage, age, histology, } \\
\text { gender and smoking status }\end{array}$ \\
\hline
\end{tabular}

*, high expression/ low expression. ER $\beta$, estrogen receptor beta; NR, not reported; EGFR, epidermal growth factor receptor. 
$\mathbf{A}$

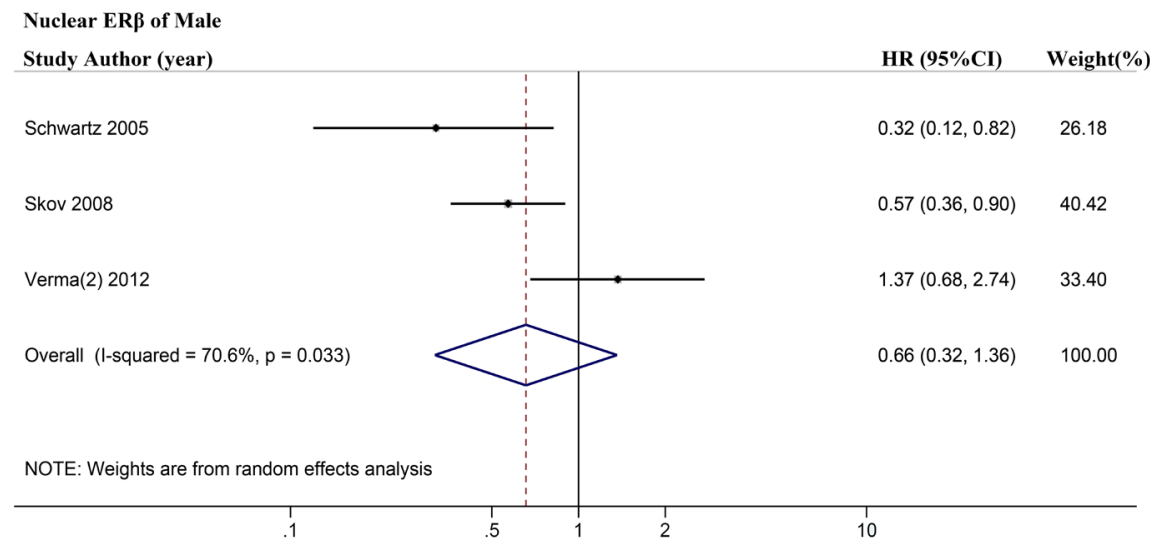

B

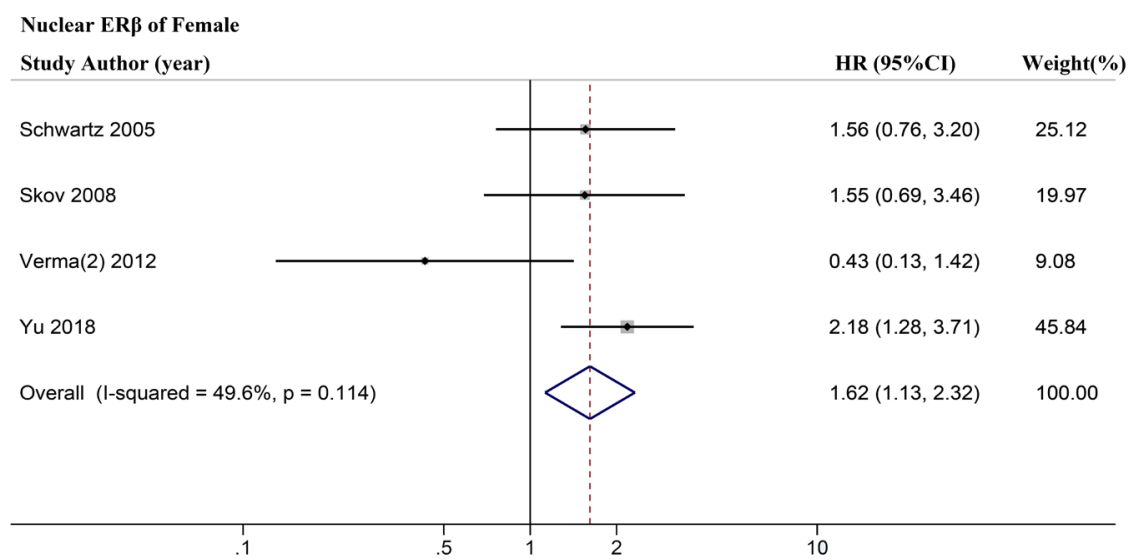

Figure S1 Forest plots of associations between nuclear ER $\beta$ protein expression and OS by sex. (A) Effect of nuclear ER $\beta$ on OS of NSCLC in male. (B) Effect of nuclear ER $\beta$ on OS of NSCLC in female. HR: hazard ratio; CI: confidence interval; ER $\beta$ : estrogen receptor beta. The size of the blocks or diamonds represents the weight and the length of the straight line represents the width of $95 \%$ CI.

NSCLC nuclear ER $\beta$ studies $(n=10)$

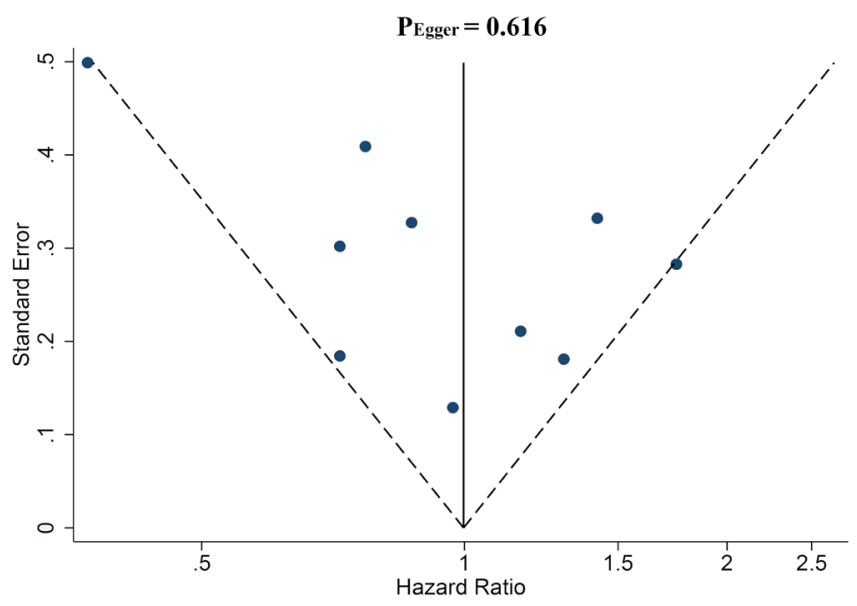

Figure S2 Funnel plot of Publication bias using Egger's test for NSCLC (excluded lung adenocarcinoma-specific studies) nuclear ER group. ER $\beta$, estrogen receptor beta; NSCLC, non-small cell lung cancer. Each dot represents a single study 
A

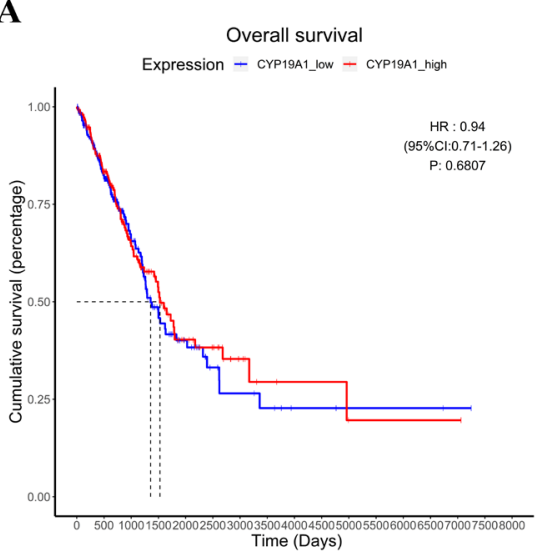

D

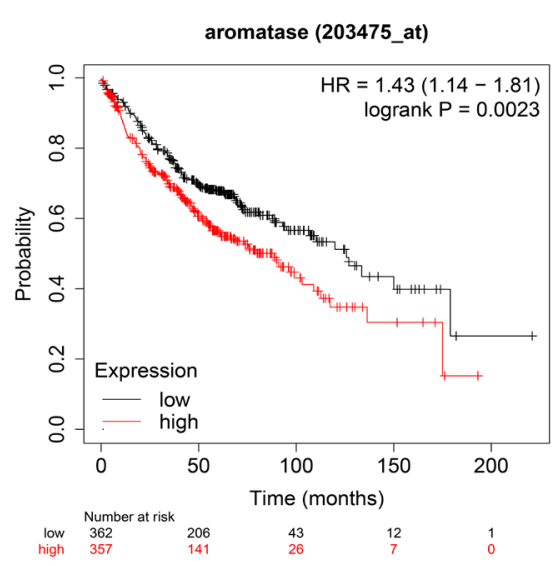

B

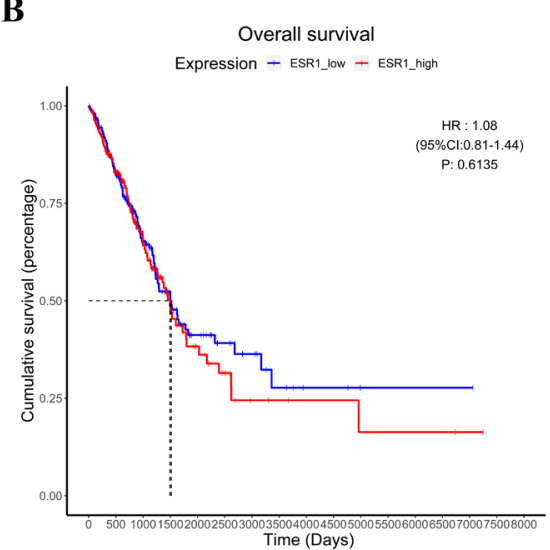

$\mathbf{E}$

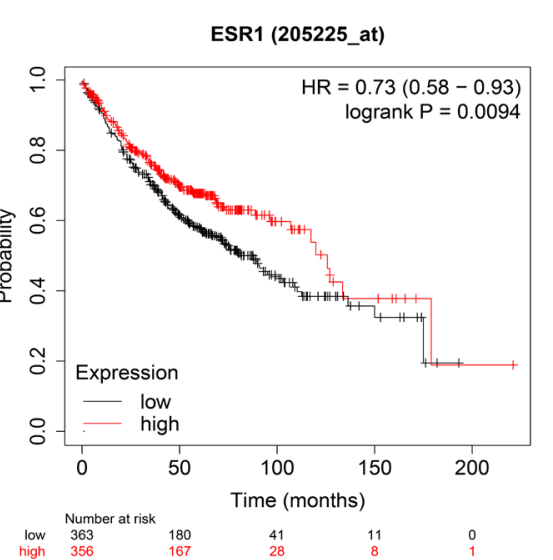

C

Overall survival Expression - GPER__Lw - GPER__ligh

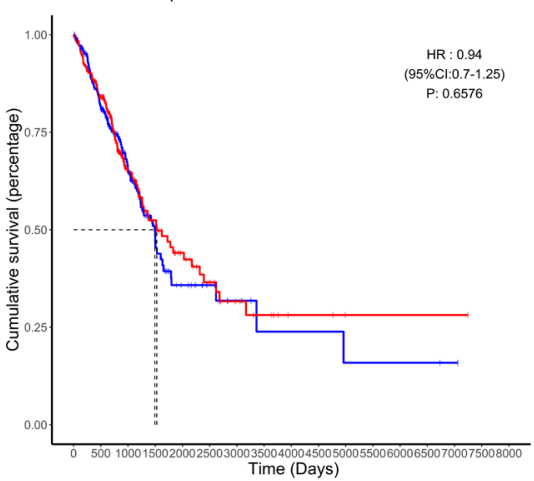

F

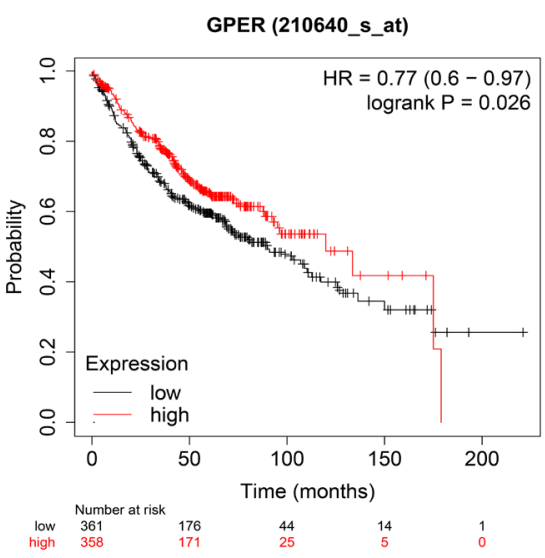

Figure S3 The Kaplan Meier curves showing association between overall survival and mRNA expression of (A) aromatase from TCGALUAD (B) ESR1 from TCGA-LUAD (C) GPER1 from TCGA-LUAD (D) aromatase from Kaplan Meier plotter (E) ESR1 from Kaplan Meier plotter (F) GPER1 from Kaplan Meier plotter. CYP19A1, aromatase; ESR1, ER $\alpha$, estrogen receptor alpha; GPER1, G-protein coupled estrogen receptor 1; HR, hazard ratio; CI, confidence interval; TCGA-LUAD, The Cancer Genome Atlas Lung Adenocarcinoma.

Table S4 The differential mRNA expression of 4 genes in lung adenocarcinoma

\begin{tabular}{llllllll}
\hline Genes & logFC & AveExpr & $t$ & P value & adj. P value & B & Change \\
\hline GPER1 & -2.07839 & 6.852989 & -10.5405 & $6.02 \mathrm{E}-24$ & $2.41 \mathrm{E}-23$ & 43.47529 & down \\
CYP19A1 & 1.176672 & 4.3038 & 5.684142 & $2.05 \mathrm{E}-08$ & $4.11 \mathrm{E}-08$ & 8.350722 & up \\
ESR2 & 0.403834 & 5.56775 & 2.67291 & 0.007724 & 0.010299 & -3.80118 & stable \\
ESR1 & 0.289788 & 8.347502 & 1.265863 & 0.206054 & 0.206054 & -6.54536 & stable \\
\hline
\end{tabular}

ESR2, ER $\beta$, estrogen receptor beta; ESR1, ER $\alpha$, estrogen receptor alpha, GPER1, G-protein coupled estrogen receptor 1; CYP19A1, aromatase. 
Table S5 Characteristics of 4 GEO datasets in lung adenocarcinoma

\begin{tabular}{|c|c|c|c|c|c|c|}
\hline GSE & GPL & Tissue & \multicolumn{2}{|c|}{ Sample type } & Reference & PMID \\
\hline GSE10072 & GPL96 & LUAD & 49 & 58 & Landi, Dracheva et al. 2008 & 18297132 \\
\hline GSE40791 & GPL570 & LUAD & 100 & 94 & Zhang, Foreman et al. 2012 & 23187126 \\
\hline GSE32863 & GPL6884 & LUAD & 58 & 58 & Selamat, Chung et al. 2012 & 22613842 \\
\hline
\end{tabular}

LUAD, lung adenocarcinoma. 